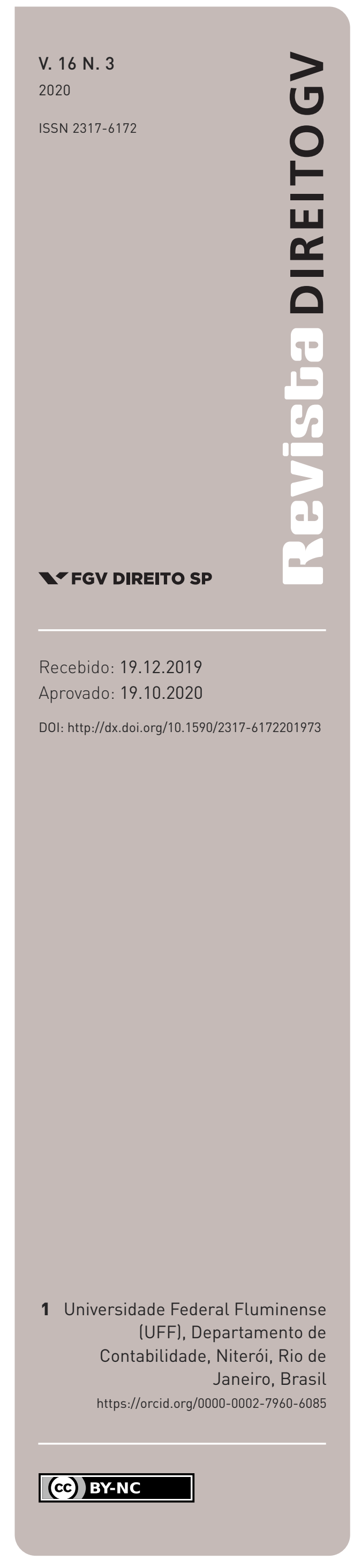

\section{Combinação de negócios entre entidades sob controle comum: um estudo dos USGAAP e dos UKGAAP e seus efeitos no ambiente societário e tributário brasileiro}

BUSINESS COMBINATION UNDER COMMON CONTROL: A STUDY OF THE USGAAP AND UKGAAP AND THEIR EFFECTS IN THE BRAZILIAN CORPORATE AND TAX ENVIRONMENT

Jorge Vieira da Costa Junior ${ }^{1}$

\section{Resumo}

As operações de combinação de negócios realizadas entre entidades sob controle comum representam um desafio a ser enfrentado por jurisdições que adotam as IFRSs. Há uma lacuna na regulação e as companhias desenvolvem políticas contábeis variadas dentro da discricionariedade conferida pela IAS n. 8, promovendo com isso perda de comparabilidade e uniformidade. A depender das motivações econômicas subjacentes, ditas políticas podem colocar em dúvida a qualidade da informação a ser disseminada aos usuários das demonstrações contábeis. Este estudo, sob uma abordagem normativa de pesquisa, tem o propósito de incursionar por práticas contábeis dos EUA e do Reino Unido voltadas à disciplina das BCUCCs e aplicá-las em exemplos ilustrativos, com o fim de avaliar efeitos de algumas dessas práticas no ambiente societário e tributário brasileiro. As simulações levadas a efeito indicam que a adoção de algumas práticas dos EUA e do Reino Unido pode requerer mudanças na lei societária brasileira.

\section{Palavras-chave}

BCUCC; controle comum; IFRS; ágio gerado internamente; participação de não controladores.

\section{Abstract}

Business Combination under Common Control represents a challenge for jurisdictions that adopt IFRS. There is a "regulation gap" and companies develop varied accounting policies under the discretion of IAS n. 8, therefore promoting a break of comparability and uniformity. Depending on the underlying economic motivations, such policies may put in doubt the quality of the information to be disclosed to users of the financial statements. This study, under a normative research approach, investigates the USGAAP and the UKGAAP focused on BCUCC and apply them to illustrative examples, in order to evaluate the effects of some of these practices in the Brazilian corporate and tax environment. The results of the illustrative examples indicate that the adoption of some accounting practices from US and from UK may require changes in the Brazilian corporate law.

\section{Keywords}

BCUCC; common control; IFRS; internally generated goodwill; non-controlling interest. 


\section{INTRODUÇÃO}

As operações de combinação de negócios realizadas entre entidades sob controle comum, reconhecidas na literatura como Business Combination Under Common Control (BCUCC), representam um desafio a ser enfrentado por algumas jurisdições mundo afora em matéria de regulação contábil, sobretudo por aquelas signatárias das IFRSs. Está na agenda do International Accounting Standard Board (IASB) desde dezembro de 2007, quando então foi apresentado o Agenda Paper - 5C, ${ }^{1}$ que discutia (i) a disciplina das transações sob controle comum (escopo mais amplo, de interesse de constituintes de algumas jurisdições) e (ii) a adoção de um cronograma inicial de trabalho, com uma minuta de um discussion paper para o primeiro trimestre de 2009. ${ }^{2}$

Em jurisdições de origem anglo-saxônica, especificamente Reino Unido - UKGAAP 3 e Estados Unidos da América - USGAAP -, a matéria já se encontra pacificada, seja normativamente, seja pela prática profissional prevalecente. Anglo-saxões entendem essas operações como transações entre sócios, por assim dizer transações de capital. E, como tais, não devem servir de gatilho para o surgimento de goodwill ou de ganho por compra vantajosa. Enfim, ditas operações não devem produzir efeitos econômicos, visto serem encaradas como uma redistribuição de capital entre sócios controladores e não controladores.

No Brasil, a matéria desperta grande interesse. Provoca também muitos debates entre os especialistas no tema, visto que defensores de uma corrente entendem que informações contábeis distintas devem ser produzidas, a depender das entidades que reportam - nível de reporte (o que concorre para a quebra do vínculo umbilical entre demonstrações individuais e consolidadas) -, ao passo que defensores de outra corrente, em linha com o pensamento anglo-saxão, entendem que há somente uma informação a ser produzida pela Entidade Econômica que reporta ${ }^{4}$ (o que concorre para a manutenção do vínculo umbilical entre demonstrações individuais e consolidadas).

Como há uma lacuna na normatização do Comitê de Pronunciamentos Contábeis (CPC), as companhias abertas no Brasil, na prática, desenvolvem políticas contábeis dentro da discri-

1 Disponível em: https://www.ifrs.org/-/media/project/business-combinations-under-common-control/ agenda-proposal-december-2007.pdf. Acesso em: 4 nov. 2020.

2 Os estudos e debates em torno do tema ficaram parados por seis anos, tendo sido retomadas as discussões somente em setembro de 2013.

3 Os Generally Accepted Accounting Principles in the UK (UKGAAP) têm alcance sobre o ambiente de regulação contábil da Escócia, da Inglaterra, do País de Gales, da Irlanda do Norte e da República da Irlanda (EIRE).

4 Assim identificada no nível da demonstração consolidada final (ultimate parent entity), a partir da qual as demonstrações individuais devem ser elaboradas para atender a exigências legais societárias e tributárias e, se for o caso, ajustadas. 
cionariedade conferida pelo pronunciamento CPC n. 23 (IAS n. 8). Interessante notar que não há uma consistência nas escolhas dessas práticas entre companhias distintas ou até mesmo para uma mesma companhia em um dado horizonte temporal. ${ }^{\mathbf{5}}$

Para compreender o porquê das escolhas contábeis advindas de uma BCUCC, é importante identificar as motivações econômicas que as justificam. No Brasil, tomando por base as autuações da Receita Federal submetidas ao Conselho Administrativo de Recursos Fiscais (CARF), as evidências revelam que as combinações de negócios entre entidades sob controle comum, em grande parte, têm motivações tributárias. ${ }^{6}$ Em jurisdições europeias, evidências empíricas indicam que há incentivos para a adoção da prática do window dress ${ }^{\mathbf{7}}$ visando à redução da alavancagem das empresas (via paid-in capital reserve) e ampliando a sua capacidade de emitir publicamente títulos de dívida.

Este trabalho tem o propósito de incursionar por práticas contábeis dos Estados Unidos da América (EUA) e do Reino Unido voltadas à disciplina das BCUCCs. Simulações, com base em exemplos ilustrativos, também são desenvolvidas com o fim de investigar efeitos societários e tributários de algumas dessas práticas no ambiente brasileiro. Justifica-se a sua importância pela lacuna em nossa regulação doméstica e na regulação das IFRSs. É pauta de regulação atual no Brasil e no exterior. Advoga-se ainda a relevância do artigo pela carência de trabalhos acadêmicos a respeito do tema. A literatura da área está sendo construída aos poucos e, dado o seu caráter multidisciplinar, é de interesse tanto de juristas quanto de profissionais de contabilidade que militam na área.

O artigo está estruturado da seguinte forma: a seção introdutória contextualiza o tema; a seção 1 apresenta práticas contábeis dos USGAAP e práticas contábeis dos UKGAAP. A seção 2

5 A esse respeito, Costa Junior (2019) analisa operação de planejamento tributário praticada no mercado brasileiro pós-Lei n. 12.973/2014, com o uso de uma BCUCC, estruturada com alternância de política contábil em curto lapso e reconhecimento dos efeitos em rubrica de OCI.

6 Pesquisa realizada no portal do CARF, disponível em: https://carf.fazenda.gov.br/sincon/public/pages/ ConsultarJurisprudencia/consultarJurisprudenciaCarf.jsf, no período compreendido de 01.01.2008 (ano de vigência da Lei n. 11.638/2007) a 31.01.2019, com a palavra-chave "ágio interno", com o filtro Ementa+Decisão, indicou a ocorrência de 160 acórdãos sobre o tema. Para o CARF, a falta de propósito negocial nas transações, a criação artificial de condições para obtenção de vantagens tributárias ou a ausência de parte independente na transação desqualificam, para fins tributários, a dedutibilidade do ágio interno amortizado.

7 Segundo Shalev, Bonacchi e Marra (2014), é uma escolha contábil oportunística (opportunistic accounting choice) por meio da qual as companhias levam a efeito as BCUCCs com vistas a remensurarem seus ativos a fair value (inflarem-nos), reduzindo com isso a alavancagem. Subsequentemente ao evento, promovem a colocação pública de títulos de dívida em vez da colocação privada, que é destinada majoritariamente aos bancos, que são imunes aos efeitos do window dress (há maior assimetria informacional em colocações públicas e menor monitoramento do que o realizado por bancos nas colocações privadas). 
apresenta as simulações desenvolvidas com auxílio de exemplos ilustrativos, que procuram explorar a adoção de algumas práticas contábeis e seus efeitos societários e tributários no Brasil. Por fim, são apresentadas as conclusões do trabalho e o referencial bibliográfico.

\section{REVISÃO DE LITERATURA}

\section{I. Padrões UKGAaP e USGAAP: Teoria normativa subjacente}

A teoria normativa sobre a qual os padrões USGAAP e UKGAAP voltados à BCUCC estão assentados é a do "Economic Unit Theory", 8 em particular no tratamento contábil a ser dispensado ao goodwill gerado internamente (transações entre controladores e não controladores são transações de capital; são redistribuições da participação de cada qual nos ativos líquidos controlados).

Por acaso esta é a teoria normativa que baliza a norma do IASB para tratamento contábil da Combinação de Negócios genuína - IFRS n. 3/CPC n. 15 (com mudança de controle da adquirida), visto que o fair value de ativos líquidos é full (e não o fair value proporcional, como é o caso do tratamento contábil empregado à luz do "Parent Concept" ou da "Contemporary Theory”) e a participação de não controladores é tratada como item integrante do Patrimônio Líquido (PL) consolidado (diferentemente do tratamento dado pelo "Parent Concept", segundo o qual a participação de não controladores é um item de passivo).

Pela "Economic Unit Theory” não se admite também o reconhecimento de um goodwill full, obtido por meio de um cálculo implícito do goodwill que seria atribuído à participação de não controladores (procedimento empregado pela "Entity Concept"), algo que seria advogar a "tese do absurdo", 9 uma vez que teria de se admitir que o goodwill - que vem a ser um item computado como resíduo de alocações do preço pago pela adquirida - fosse mensurado indiretamente ao valor justo. ${ }^{10}$

8 Um estudo de teorias normativas para demonstrações consolidadas - "Entity Concept", "Parent Concept", "Contemporary Theory" e "Economic Unit Theory" - é feito por Costa Junior e Martins (2006).

9 A “tese do absurdo” foi bem trabalhada por Zenão de Eleia, filósofo pré-socrático 490-439 a.C., que se notabilizou por oferecer, com forte rigor, linhas de argumentação assentadas em paradoxos. Defendia o pensamento filosófico de seu mestre Parmênides acerca do universo. Um de seus mais famosos paradoxos ilustra a ideia de limites em matemática: o paradoxo de "Aquiles e a tartaruga", que tenta provar a ideia advogada por Parmênides contra o movimento. O movimento seria, segundo Parmênides, ilusão dos sentidos.

10 O cálculo implícito de goodwill de não controladores é advogado pela teoria normativa do "Entity Concept". No documento "Basis for Conclusions" da IFRS n. 3, §§BC205-BC221, toma-se conhecimento do debate que conduziu o board do IASB a tomar sua decisão em termos de mensuração da participação de não controladores (PÑC) e que culminou na não admissão do goodwill implícito. Hoje, nos termos do §19 
Como há um vazio normativo nas IFRSs, a ideia do autor, seguindo a diretriz traçada pela IAS n. $8^{11}$ para o desenvolvimento de uma política contábil, foi recorrer a GAAPs cujo arcabouço conceitual fosse similar ao adotado pelas IFRSs. Normas de jurisdições anglo-saxônicas, sobretudo Reino Unido, berço das IFRSs.

\section{I.2. A REGULAÇÃo DOTEMA NOS EUA - USGAAP}

Nos EUA, a regulação em matéria contábil está reunida no que a literatura denomina Generally Accepted Accounting Standards in the United States (USGAAP). Os USGAAP são compostos por uma série de documentos emitidos por algumas entidades nos EUA, sendo de observância obrigatória por parte de companhias emissoras de valores mobiliários, conforme endosso da The United States Securities and Exchange Commission (USSEC), o regulador local do mercado de capitais.

Aqui cabe uma breve explanação. Com a nova codificação instituída pelo Financial Accounting Standards Board (FASB) a partir de 01.07.2009 - Accounting Standard Codification (ASC),

da IFRS n. 3, é admitida uma escolha contábil: fair value da PÑC ou valor proporcional nos ativos líquidos da adquirida. E, considerando o fair value, a IFRS n. 3, em seu §§B44-B45, admite a cotação em mercado ativo da PÑC. Caso os participantes de mercado precifiquem eventual prêmio de controle na cotação, o valor cotado precisará considerar ou desconsiderar dito componente (no Brasil, dada a previsão legal para ações ordinárias e eventualmente estatutária de cada companhia para ações preferenciais, o prêmio de controle - tag along da LSA, art. 254-A - deve ser incluído na PÑC).

11 IAS 8, §10. "In the absence of an IFRS that specifically applies to a transaction, other event or condition, management shall use its judgement in developing and applying an accounting policy that results in information that is:

(a) relevant [Refer: Conceptual Framework paragraphs 2.6-2.11] to the economic decision making needs of users; [Refer: Conceptual Framework paragraphs 1.2-1.10 and 2.36] and

(b) reliable, in that the financial statements:

(i) represent faithfully [Refer: Conceptual Framework paragraphs 2.12 and 2.13] the financial position, financial performance and cash flows of the entity;

(ii) reflect the economic substance [Refer: Conceptual Framework Basis for Conclusions paragraphs $\mathrm{BC} 2.32$ and $\mathrm{BC} 2.33$ ] of transactions, other events and conditions, and not merely the legal form;

(iii) are neutral, [Refer: Conceptual Framework paragraph 2.15] ie free from bias;

(iv) are prudent; [Refer: Conceptual Framework Basis for Conclusions paragraphs BC2.34 and BC2.45] and

(v) are complete [Refer: Conceptual Framework paragraph 2.14] in all material respects" (grifos do autor).

IAS n. 8, §12. "In making the judgement described in paragraph 10, management may also consider the most recent pronouncements of other standard setting bodies that use a similar conceptual framework to develop accounting standards, other accounting literature and accepted industry practices, to the extent that these do not conflict with the sources in paragraph 11. [Refer also: Basis for Conclusions paragraphs BC16-BC19]" (grifos do autor). 
os USGAAP passaram a estar reunidos em tópicos temáticos, em um único lugar (cerca de 90 tópicos temáticos atualmente). Até então, os USGAAP “pré-codificação" - denominados grandfathered material - estavam esparsamente distribuídos, em um modelo baseado em padrões específicos pormenorizados (milhares de pronunciamentos individuais, emitidos por algumas entidades). ${ }^{12}$

Estão contemplados na atual codificação os seguintes documentos, condensados e agrupados em tópicos temáticos:

A. Documentos emitidos pelo FASB:

a. Statement on Financial Accounting Standard (SFAS);

b. FASB Interpretations (FIN);

c. FASB Technical Bulletins (FTB);

d. FASB Staff Positions (FSP);

e. FASB Staff Implementation Guides (Q\&A);

f. FASB Statement n. 138 Examples: tratamento contábil para certos derivativos financeiros e certas atividades de hedge.

B. Documentos emitidos pelo Emerging Issues Task Force (EITF) do FASB: ${ }^{13}$

a. Abstracts;

b. Topic D.

C. Derivative Implementation Group (DIG) Issues;

D. Accounting Principles Board (APB) Opinions;

E. Accounting Research Bulletins (ARB);

F. Accounting Interpretations (AIN);

12 Para um aprofundamento no estudo da estrutura de regulação dos USGAAP, recomenda-se a leitura do documento intitulado "FASB Accounting Standard Codification", que elucida em 46 páginas a nova codificação. Disponível em: https:// asc.fasb.org/imageRoot/47/49128947.pdf. Acesso em: 4 nov. 2020.

13 Força-tarefa para assuntos emergentes e prementes em matéria de regulação contábil, da qual participa como observador, sem direito a voto, mas com direito de ser ouvido ("privilege of the floor"), o "Chief Accountant da USSEC” ou o "Deputy Chief Accountant da USSEC” (2 na linha sucessória). (Disponível em: https: / / www. fasb.org/jsp/FASB/Page/SectionPage\&cid=1218220137512. Acesso em: 21 nov. 2020.) 
G. Documentos emitidos pelo American Institute of Certified Public Accountants (AICPA):

a. Statements of Position (SOP);

b. Audit and Accounting Guides (AAG): somente orientação em matéria contábil;

c. Practice Bulletins $(\mathrm{PB})$;

d. Technical Inquiry Service (TIS): somente para reconhecimento de receita com software.

Ainda estão contemplados nos USGAAP, também condensados e agrupados em tópicos temáticos, excertos relevantes em matéria contábil e de disclosure, extraídos de manifestações e regulação da USSEC, a saber:

I. Regulation S-X (SX);

II. Financial Reporting Releases (FRR)/Accounting Series Releases (ASR);

III. Interpretive Releases (IR);

IV. SEC Staff guidance:

a. StaffAccounting Bulletins (SAB);

b. EITF Topic D and SEC Staff Observer comments.

Percebe-se quão árdua era a tarefa daqueles que militavam na área de contabilidade e de auditoria no ambiente norte-americano, ao operarem os USGAAP "pré-codificação". Com a nova codificação, ficou mais fácil interpretar e aplicar os USGAAP, sobretudo pelo fato de o FASB colocar ao dispor dos usuários ferramentas de navegação e de pesquisa dos seus dispositivos, reunidos em meio digital (Codification Research System).

Feita essa elucidação, cabe compulsar as disposições dos USGAAP voltadas às BCUCCs. Nesse particular, o tópico temático 805 - Business Combination, em seu subtópico 805.50 Related Issues, trata das transações entre entidades sob controle comum. ${ }^{14}$ Uma transação entre entidades sob controle comum compreende a transferência de ativos ou a troca de participações societárias entre entidades sob o controle de um mesmo controlador. Essas

14 Com tratamento contábil disciplinado nos $\S \S 805.50 .05 .4$ e 805.50.05.5 (visão geral e contexto histórico); nos $\S \S 805.50 .15 .5,805.50 .15 .6,805.50 .15 .6 \mathrm{~A}$ e $805.50 .15 .6 \mathrm{~B}$ (escopo e exceções); no $\S$ 805.50.25.2 (reconhecimento contábil); nos $\$ \S 805.50 .30 .5$ e 805.50.30.6 (mensuração contábil inicial); nos $\S \S 805.50 .45 .1,805.50 .45 .2,805.50 .45 .3,805.50 .45 .4$ e 805.50.45.5 (outras matérias relativas à apresentação contábil); nos $\S \S 805.50 .50 .1,805.50 .50 .2,805.50 .50 .3,805.50 .50 .4$ e 805.50.50.5 (evidenciação contábil) e no § 805.50.S99.4 (manifestação de observador da SEC em reunião do EITF do FASB). 
transferências podem envolver negócios, ativos não monetários, por exemplo imobilizados e estoques, ou ainda instrumentos financeiros.

Uma lista não exaustiva de transações entre entidades sob controle comum, apresentada no parágrafo 805.50.15.6 da norma, compreende:

: a entidade constitui uma nova entidade - newly formed entity - e transfere alguns ou todos os seus ativos líquidos para essa entidade;

: a companhia controladora absorve em seu patrimônio os ativos líquidos de uma subsidiária integral e liquida posteriormente essa subsidiária integral;

: a companhia controladora transfere diversas participações societárias detidas em companhias controladas para uma nova companhia controlada constituída;

: a companhia controladora troca participação societária detida em uma subsidiária integral por participação societária adicional em uma controlada, sem excluir a participação de não controladores nesta última;

: uma companhia controlada emite ações em troca de participação societária em outra controlada, anteriormente detida pela companhia controladora, sem excluir a participação de não controladores;

: uma companhia de responsabilidade limitada é constituída pela combinação de entidades sob controle comum;

: duas ou mais entidades sem fins lucrativos (Not-for-Profit Entities - NFP), efetivamente controladas pelo mesmo conselho de administração, transferem seus ativos líquidos para uma nova entidade, com a dissolução das entidades combinadas, e indicam o mesmo conselho de administração para dirigir a nova entidade resultante da combinação.

As orientações dos USGAAP aplicáveis às transações entre entidades sob controle comum alcançam todas as entidades. Entretanto, transações celebradas entre o beneficiário primário de ativos, de passivos ou de uma participação não controladora em uma Variable Interest Entity (VIE) ${ }^{15}$ e a própria VIE, nos termos do parágrafo $805.50 .15 .6 \mathrm{~A}$ da niais (majority of voting rights), mas por meio de participações variáveis definidas contratualmente. Uma VIE 
norma, não são alcançadas para fins de mensuração contábil inicial, se ambos beneficiário primário e VIE - estiverem sob um controle comum. Ainda estão fora do escopo, nos termos do parágrafo $805.50 .15 .6 \mathrm{~B}$ da norma, as fusões e aquisições ${ }^{16}$ envolven- $^{-}$ do duas ou mais entidades sem fins lucrativos (NFPs), não consideradas transações sob controle comum. ${ }^{17}$

Tratando-se de reconhecimento contábil, conforme os USGAAP, a entidade que recebe os ativos líquidos qualificados como um negócio (uma BCUCC), ou participações societárias, deve registrá-los em suas demonstrações contábeis, na data da transferência, nos termos do parágrafo 805.50.25.2 da norma.

Se o valor contábil dos ativos líquidos transferidos diferir do custo histórico desses mesmos ativos, sob a perspectiva do controlador das entidades sob controle comum combinadas (parent's perspective), em decorrência de não ter sido aplicado o método do pushdown accounting na última combinação de negócios genuína que antecedeu a transação, as demonstrações contábeis da entidade que recebe os ativos líquidos devem refletir o valor contábil desses ativos, sob a perspectiva do controlador das entidades sob controle comum combinadas (predecessor cost accounting), nos termos do parágrafo 805.50.30.5 da norma. Qualquer diferença entre a contraprestação transferida e o valor contábil dos ativos recebidos deve ser reconhecida como uma transação de capital, em uma reserva de paid-in capital (espécie de reserva de capital).

Sobre o método do pushdown accounting, pode-se dizer que as orientações para sua aplicação constam na codificação dos USGAAP no mesmo tópico temático 805 - Business Combination, no mesmo subtópico 805.50 - Related Issues. Ditas orientações aplicam-se às demonstrações contábeis separadas da companhia adquirida e às de suas controladas, sendo uma prática contábil opcional, a ser eleita a cada evento de obtenção de controle (ASC 805.50.25.4 e ASC 805.50.25.6), sendo irrevogável essa decisão (ASC 805.50.25.9).

em regra tem um beneficiário primário, que é aquela outra entidade ou terceiro que detém a maioria das participações variáveis (majority of variable interests). Se o beneficiário primário for uma companhia listada, toda a carteira de ativos da VIE deverá ser apresentada nas suas demonstrações contábeis. O uso de VIEs foi muito comum entre instituições financeiras nas securitizações das suas carteiras de empréstimos hipotecários - Mortgage Backed Securities (MBS), em especial os subprimes. As VIEs foram utilizadas pelas instituições financeiras como veículos de propósito especial (SPEs) para evitar que ativos de altíssimo risco fossem apresentados em suas demonstrações contábeis, via seu desreconhecimento em operações de securitização, "melhorando" a fotografia do risco tomado pela instituição.

De acordo com o conceito anglo-saxão, qual seja, o de fusão de controle e de aquisição de controle.

17 Muito embora as NFPs beneficiem um grupo particular de indivíduos, dito grupo não detém a propriedade e tampouco o controle de uma NFP. 
A companhia adquirida, uma vez feita a escolha do pushdown accounting, deve empregar aos seus ativos líquidos, em suas demonstrações contábeis separadas, a mesma base de mensuração contábil adotada pela companhia adquirente para esses mesmos ativos líquidos no consolidado, após o evento de obtenção de controle. Em síntese, a base de mensuração do controlador, uma vez adotado o pushdown, deve estar espelhada nas demonstrações contábeis separadas da adquirida (ASC 805.50.30.10).

O goodwill deverá ser reconhecido pela adquirida em suas demonstrações contábeis separadas quando da adoção do pushdown, mas o ganho por compra vantajosa não poderá transitar pela sua demonstração de resultado. O ganho por compra vantajosa deverá ser reconhecido como um ajuste da conta de paid-in capital (espécie de reserva de capital) nas demonstrações contábeis separadas da companhia adquirida (ASC 805.50.30.11). Eventual passivo relacionado à aquisição da companhia adquirida deverá ser reconhecido pela companhia adquirida via pushdown em suas demonstrações contábeis separadas se, e somente se, representar de fato uma obrigação da adquirida, ${ }^{18}$ conforme disposições de outros USGAAP aplicáveis (ASC 805.50.30.12).

Assim, eventual passivo relacionado à aquisição da companhia adquirida deverá ser reconhecido, via pushdown, em suas demonstrações contábeis separadas se, e somente se, (i) o passivo for uma obrigação legal da adquirida ou (ii) o adquirente e a adquirida forem severamente solidários e responsáveis pelo passivo (ASC 405.40.30.1, subtópico Obligations Resulting from Joint and Several Liability Arrangements).

Outra questão que pode surgir na aplicação do pushdown está relacionada às diferenças de critérios contábeis observadas entre os ativos transferidos e os ativos de mesma natureza da entidade que recebe. Nessas circunstâncias, ditas diferenças podem ser ajustadas por meio de uniformização de critérios, utilizando a base adotada pela entidade que recebe, se essa mudança for a preferível. O referido ajuste deverá ser aplicado retrospectivamente e as demonstrações contábeis apresentadas em períodos anteriores deverão ser ajustadas, a menos que seja impraticável fazê-lo, nos termos do parágrafo 805.50.30.6 da norma.

Passando à apresentação das demonstrações contábeis separadas da entidade que recebe os ativos transferidos, seja no período corrente da transação, seja em períodos anteriores

18 São observadas, por vezes, operações de aquisição de controle altamente alavancadas, segundo as quais empresas menores obtêm financiamentos para tal propósito. São cunhadas na literatura como leveraged buyouts (LBOs). Essas aquisições alavancadas podem ser levadas a efeito também por executivos do setor, financiados por bancos de investimento ou pela indústria de private equity. São as denominadas management buyouts (MBOs). Aquisições alavancadas foram muito frequentes no mercado norte-americano no ano de 1985, quando foram utilizadas por parte de firmas especializadas como estratégia visando a desmantelar companhias adquiridas - as bust-up take overs (compra da companhia para posterior venda de seus "pedaços", visto que as suas partes valiam mais do que o todo à época). 
comparativos, o tratamento contábil requerido pelos USGAAP irá depender do julgamento profissional a ser feito para avaliar se houve ou não mudança da entidade que reporta.

A regra geral dos USGAAP é que, quando uma mudança contábil resulte em demonstrações contábeis que são efetivamente demonstrações contábeis de uma nova entidade que reporta (a new reporting entity), a mudança deve ser aplicada retrospectivamente às demonstrações contábeis de períodos anteriores, de modo a serem reportadas informações financeiras da nova entidade que reporta (ASC 250.10.45.21). E uma mudança na entidade que reporta será observada quando (ASC 250.10.20):

(i) for requerida a apresentação de demonstrações contábeis consolidadas ou combinadas no lugar das demonstrações contábeis das entidades individuais;

(ii) ocorrerem mudanças em controladas específicas que fazem parte do grupo de entidades para as quais demonstrações contábeis consolidadas são apresentadas; ou

(iii) ocorrerem mudanças nas entidades incluídas nas demonstrações contábeis combinadas.

Se tiver ocorrido a mudança da entidade que reporta, o tratamento contábil, em termos de informações comparativas, é similar ao previsto na aplicação do método do pooling-ofinterest. ${ }^{19}$ A Demonstração do Resultado (DRE) da entidade que recebe os ativos transferidos deve contemplar os resultados de operações advindas dos ativos recebidos e das participações societárias recebidas, como se a transferência tivesse ocorrido no início do período, com a eliminação das transações entre as companhias combinadas. Do mesmo modo devem ser apresentados o Balanço Patrimonial (BP) e a Demonstração dos Fluxos de Caixa (DFC). Demonstrações contábeis de períodos anteriores devem ser ajustadas de modo retrospectivo, a fim de garantir sua comparabilidade (resguardar a qualidade das séries históricas das variáveis contábeis, evitando surgimento de quebras estruturais não justificadas economicamente).

Caso não tenha ocorrido a mudança da entidade que reporta, a DRE da entidade que recebe os ativos transferidos deve contemplar os resultados de operações advindas dos ativos recebidos e das participações societárias recebidas, a partir da data da transação. O BP e a DFC

19 Método contábil alternativo, que era empregado no ambiente de regulação norte-americano às combinações de negócios genuínas, enquadradas nas condicionantes estabelecidas pelo Accounting Principles Board (APB) Opinion n. 16. Os ativos líquidos das companhias combinadas eram reconhecidos a valor de livros e havia a consolidação integral dos resultados das operações no período de ocorrência da combinação, independentemente da data da operação (se no início, no meio ou no final do período). 
do mesmo modo devem ser apresentados. Demonstrações contábeis de períodos anteriores não devem ser ajustadas, visto que o tratamento contábil é aplicado de modo prospectivo.

$\mathrm{Na}$ prática, o tratamento mais frequentemente observado é a apresentação retrospectiva das demonstrações contábeis separadas da entidade que recebe. ${ }^{20}$

Como se pode constatar, a codificação USGAAP, ao disciplinar as transações entre entidades sob controle comum, foca no tratamento a ser dispensado para fins de demonstrações contábeis separadas da entidade que recebe os ativos ou a participação societária. Para a entidade que transfere ativos ou participações societárias, em uma transação sob controle comum, a prática contábil foi desenvolvida ${ }^{21}$ com base em tratamento análogo ao dispensado à entidade que recebe.

Em síntese, dois são os métodos contábeis aceitos pela prática profissional:

: depooling, caso seja julgado que houve mudança na entidade que reporta: os ativos líquidos transferidos e as respectivas operações são removidos retrospectivamente da entidade que transfere, com base em seus valores históricos (similar a um spin-off). Qualquer diferença entre a contraprestação recebida e o valor contábil dos ativos transferidos deve ser reconhecida como uma transação de capital, em uma reserva de paid-in capital (espécie de reserva de capital). O depooling não é muito aceito pelo corpo técnico da USSEC, sendo as companhias fortemente desafiadas a atenderem condicionantes impostas para sua aplicação; ou

: aplicação dos USGAAP voltados ao ato de dispor ativos de longa vida útil, que não seja pela venda (long-lived assets to be disposed of other than by sale): os ativos líquidos devem ser mantidos na entidade que transfere, e classificados como mantidos em uso, até a efetivação da transferência, a qual deve ser reconhecida pelo valor contábil dos ativos transferidos. Qualquer diferença entre a contraprestação recebida e o valor contábil dos ativos transferidos deve ser reconhecida como uma transação de capital, em uma reserva de paid-in capital (espécie de reserva de capital). Este é o método preferencial admitido pelo corpo técnico da USSEC, sendo por consequência mais frequentemente aplicado.

"In practice, the method that many entities have used to account for those transactions is similar to the pooling-of-interest method” (ASC 805.50.05.5).

A esse respeito, orientações podem ser obtidas no documento intitulado $A$ roadmap to common-control transactions (DELOITTE, 2016, p. 10-11), editado pela firma de auditoria Deloitte. Também podem ser obtidas orientações no manual Business combinations and non-controlling interests - Application of the U.S. GAAP and IFRS Standards (PWC, 2014, p. 8.23-8.25, Capítulo 8). 
Um ponto de especial atenção é o tratamento contábil a ser dado ao goodwill (nesse caso só o genuíno) a ser transferido, pela entidade que transfere. O montante a ser transferido poderá ser obtido por meio de alocações do goodwill, previamente feitas em controles gerenciais, a Unidades Geradoras de Caixa (UGCs) e a ativos, para fins de teste de impairment, caso não seja transferido um negócio. Caso seja transferido um negócio, o montante integral do goodwill a ele associado será transferido. Há ainda a possibilidade de se obter o montante do goodwill a ser transferido por meio de valores justos relativos dos ativos e UGCs a ele associados, na inexistência de controles gerenciais.

Outro ponto de grande importância a ser observado no tratamento contábil a ser empregado às transações entre entidades sob controle comum reside nas exceções à regra geral de mensuração. A regra geral é a do predecessor cost basis, tanto pela entidade que recebe quanto pela entidade que transfere. Entretanto, a mensuração ao valor justo ou pelo valor negociado (stepped-up value) deve ser adotada, com o consequente reconhecimento de ganhos e perdas nas demonstrações contábeis separadas, quando envolver a transferência de instrumentos financeiros entre controladas e a transferência rotineira de mercadorias em estoque.

Tal orientação dos USGAAP encontra amparo em manifestação de observador da USSEC reproduzida no FASB EITF Issue 85-21, incorporada à nova codificação - Measurement of Certain Transfers Between Entities Under Common Control in The Separate Financial Statements of Each Entity (ASC 805.50.S99.4).

A esse respeito, cabe reproduzir referida manifestação:

As visões do corpo técnico da SEC acerca do valor contábil com base no custo histórico para registrar, nas demonstrações contábeis separadas de cada entidade, as transferências entre companhias sob controle comum ou entre uma companhia controladora e sua controlada estão voltadas a transferências de ativos líquidos (como no caso de uma combinação de negócios) ou ativos de longa vida útil. Referidas visões não seriam aplicadas normalmente a transações recorrentes para as quais a avaliação não esteja em questão (como é o caso de transferências rotineiras de estoques), quando da preparação de demonstrações contábeis separadas de cada entidade que é parte na transação. (tradução livre e grifos nossos) ${ }^{22}$

"The SEC staff's views on carrying over historical cost to record, in the separate financial statements of each entity, transfers between companies under common control or between a parent and its subsidiary are focused on transfers of net assets (as in business combination) or long-lived assets. Those views would not normally apply to recurring transactions for which valuation is not in question (such as routine transfers of inventory) in the separate financial statements of each entity that is a party to the transaction" (ASC 805.50.S99.4). 
Para a mensuração ao valor justo dos ativos financeiros transferidos em uma transação entre entidades sob controle comum e o consequente reconhecimento de ganhos e perdas nas demonstrações contábeis separadas, é necessário que a transferência se qualifique como uma venda, devendo observar as condicionantes impostas pelo ASC 806.10.40.5 - Tópico Transfers and Servicing, seção Derecognition, quais sejam:

(i) os ativos financeiros transferidos estão blindados, livres do alcance da entidade que os transfere ou de seus credores, sobretudo em caso de falência;

(ii) a entidade que recebe os ativos financeiros em transferência tem pleno direito de dá-los em garantia ou de trocá-los; e

(iii) a entidade que transfere os ativos financeiros, suas afiliadas consolidadas (coligadas sobre as quais o controle é exercido por participações variáveis - VIEs) ou seus agentes não mantêm o efetivo controle sobre os ativos financeiros transferidos, tampouco sobre os benefícios advindos dos ativos financeiros transferidos - beneficial interests,$-{ }^{23}$ cujos beneficiários sejam terceiros.

Ganhos e perdas reconhecidos em transações entre controladas envolvendo transferências de ativos financeiros são reconhecidos nas demonstrações contábeis separadas, porém são eliminados nas demonstrações contábeis consolidadas. Por essa razão, não é admitido pelos USGAAP que uma transferência de ativos financeiros da companhia controladora para sua controlada seja qualificada como uma venda, visto que esses ativos financeiros a posteriori serão incluídos nas demonstrações contábeis consolidadas. Contudo, o reconhecimento dos ativos financeiros transferidos poderá ser feito pela companhia controlada em suas demonstrações contábeis separadas, a menos que a natureza da operação seja a de um empréstimo com garantia dos ativos financeiros (ASC 860.10.55.17D).

Já para a mensuração ao valor negociado (stepped-up value) não há maiores dificuldades, sendo reconhecidos nas demonstrações contábeis separadas os lucros e prejuízos originados de transações rotineiras com mercadorias em estoque, entre entidades sob controle comum. Esses ganhos e perdas são eliminados quando da consolidação das demonstrações contábeis.

Por fim, com relação ao tratamento contábil a ser dispensado à participação de não controladores, em uma transação entre entidades sob controle comum que envolva um negócio,

23 Direitos de receber parte ou a totalidade dos fluxos de caixa recebidos pelo trust (fundo que abriga os ativos transferidos). Podem compreender prioridade ou subordinação à parcela de juros ou sua totalidade, ao principal, a juros residuais ou a outras espécies de fluxos de caixa previstos. 
de acordo com os USGAAP, qualquer mudança na participação do controlador (aumento ou diminuição) que não implique mudança de controle será tratada como uma transação de capital. O valor contábil da participação de não controladores deverá ser ajustado para refletir as alterações na distribuição das participações societárias na controlada. Qualquer diferença entre o valor justo da contraprestação recebida ou paga e o montante pelo qual a participação de não controladores for ajustada deverá ser reconhecida dentro do patrimônio líquido consolidado, na participação atribuída ao controlador. ${ }^{24}$

\section{I.3. A regulação dotema no Reino Unido - UKGAAP}

No ambiente de regulação do Reino Unido, as regras vigentes para tratamento contábil de transações entre entidades sob controle comum estão contidas basicamente no Financial Reporting Standard (FRS) n. 102, emitido em agosto de 2014 e atualizado em setembro de 2015; na Section n. 19, $\S \S 19.27-19.28$, e no Companies Act (CA) de 2006. Institutos de Contadores Públicos Certificados, subsidiariamente, emitem também orientações em documentos técnicos acerca de como operacionalizar essas regras.

Nesse sentido, o FRS n. 102, em sua seção n. 19, disciplina a forma pela qual serão tratadas contabilmente as combinações de negócios e o goodwill, positivo ou negativo ${ }^{25}$ (negative goodwill - §19.24). Regra geral, nos termos do §19.6 da norma, todas as combinações de negócios são contabilizadas pelo método da compra, à exceção das reestruturações de grupos (group reconstructions), que podem ser contabilizadas pelo método contábil da fusão ${ }^{26}$ (merger accounting method) e as combinações de negócios envolvendo entidades de utilidade pública (public benefit entity), que sejam em essência uma doação (that are in substance a gift) ou uma fusão entre iguais (merger), essas duas últimas tratadas na seção 34, Specialised Activities, da FRS n. 102.

24 “Changes in a parent's ownership interest while the parent retains its controlling financial interest in its subsidiary shall be accounted for as equity transactions (investments by owners and distributions to owners acting in their capacity as owners). Therefore, no gain or loss shall be recognized in consolidated net income or comprehensive income. The carrying amount of the non-controlling interest shall be adjusted to reflect the change in its ownership interest in the subsidiary. Any difference between the fair value of the consideration received or paid and the amount by which the non-controlling interest is adjusted shall be recognized in equity attributable to the parent" (ASC 810.10.45.23, grifo nosso).

25 Não há referência à designação terminológica utilizada pelas IFRSs, qual seja: "ganho por compra vantajosa".

26 "Merger accounting should only be used where combinations are not, in substance, the acquisition of an entity (or another institution) by an institution but the formation of a new reporting institution as a substantially equal partnership where no party is dominant" (SORP, §13.1). "The use of merger accounting is also permitted where a business combination occurs under common control” (SORP, §13.10). 
A respeito das reestruturações de grupos, o Conselho Contábil do Financial Reporting Council (FRC) ${ }^{\mathbf{2 7}}$ aconselhou o FRC, ${ }^{28}$ quando da elaboração do FRS n. 102, a manter as principais diretrizes fixadas no pronunciamento anterior, FRS n. 6 - Acquisitions and Mergers - para as reestruturações de grupo, visto que eram bem compreendidas e forneciam orientações úteis.

Uma reestruturação de grupo, conforme definição no glossário da norma, está enquadrada em qualquer um dos seguintes arranjos societários:

: a transferência de participação em uma controlada, de uma entidade do grupo para outra;

: a adição de uma nova entidade controladora no grupo;

: a transferência de participação em uma ou mais controladas, para uma nova entidade não integrante do grupo, mas cujos acionistas sejam os mesmos que integram a entidade controladora do grupo;

: a combinação em um grupo de duas ou mais entidades, que antes da combinação possuíam os mesmos acionistas.

Adicionalmente, o texto do FRS n. 102, no seu $\$ 19.28$, salienta que, muito embora a redação dos $\S \S 19.29$-19.32 e 19.33, voltados respectivamente à disciplina do método contábil da fusão (merger accounting method) e ao disclosure mínimo a ser dado em nota explicativa para as reestruturações de grupo, faça referência a uma entidade adquirente ou a uma entidade emissora, que emitem ações como contraprestação pela transferência para elas de ações de outras partes envolvidas na combinação, ditas disposições normativas devem ser lidas de tal modo que sejam aplicadas a outros arranjos de operações que alcancem resultados similares.

A prática profissional tem entendido que, uma vez observadas as condições para aplicação do método contábil da fusão (merger accounting method), arranjos de operações que alcancem resultados similares englobariam a aquisição, por uma entidade do grupo, de ativos

27 O Conselho Contábil do FRC é um órgão de assessoria do FRC, responsável por assisti-lo no estabelecimento de padrões contábeis.

28 O FRC é o regulador do Reino Unido, responsável por regular auditores, contadores e atuários, e por estabelecer os padrões de Governança Corporativa e os Códigos de Conduta de Administradores no Reino Unido (stewardship codes). 
negociáveis ou ativos líquidos de outra entidade do grupo. ${ }^{29}$ Referidas operações são cunhadas na literatura como transações hive across, segundo as quais duas entidades sob controle comum transferem entre si ativos negociáveis ou ativos líquidos. São enquadradas ainda para aplicação do método contábil da fusão, segundo a prática profissional, as transações hive down, segundo as quais uma entidade transfere ativos negociáveis ou ativos líquidos para uma controlada sua existente ou uma nova controlada sua, dentro do grupo.

Para uma reestruturação de grupo receber o tratamento contábil do método contábil da fusão, as seguintes condições devem ser observadas conjuntamente (FRS 102, §19.27):

(i) o uso do método contábil da fusão não for proibido pela lei societária do Reino Unido (Companies Act 2006) ou outra legislação relevante;

(ii) os acionistas com participações societárias no topo do grupo (ultimate equity holders) permanecerem os mesmos, e os direitos de cada um desses acionistas, com relação aos demais, não se alterarem; e

(iii) não ocorrer alteração na participação de não controladores nos ativos líquidos do grupo, por força da transferência de ativos.

De acordo com a lei societária do Reino Unido (Companies Act 2006), emendada pelos Statutory Instruments de 2015 n. 980, SI 2015/980, para aplicação do método contábil da fusão (merger accounting method), as seguintes condições devem ser atendidas conjuntamente:

(i) a empresa cujas ações são adquiridas está sob controle dos mesmos acionistas finais (ultimately controlled by the same party), antes e após a aquisição;

(ii) o controle referido em “i” não é transitório; e

(iii) a adoção do merger accounting method está em consonância com os UKGAAP ou com a prática profissional.

Assim, o método contábil da fusão tem sido adotado majoritariamente nas combinações de negócios entre entidades sob controle comum no Reino Unido e nos arranjos de transações

29 Informações a esse respeito podem ser encontradas em The Financial Reporting Group of EY (2017, p. 951), item 5.1. E ainda podem ser encontradas em UK Accounting Consulting Services of PWC (2013, p. 19045), item 19.172. 
hive across e hive down, ainda que seja uma escolha contábil a ser feita pela administração das companhias envolvidas. A prática profissional entende que o método da compra não é apropriado quando não há alteração em direitos relativos dos acionistas no topo do grupo (ultimate equity holders), visto que não fornece uma visão justa e verdadeira. ${ }^{30} \mathrm{E}$, mais ainda, mesmo que não haja o enquadramento no FRS n. 102 para fins de aplicação do merger accounting method, a prática profissional entende que deve ser utilizado o expediente do true and fair override para o descumprimento da norma nesses casos. ${ }^{31}$

A regra do true and fair override impõe a preparadores, auditores e responsáveis pela governança das companhias o descumprimento dos UKGAAP ${ }^{32}$ sempre que sua adoção resultar em demonstrações contábeis distanciadas da "visão justa e verdadeira", prevista na lei societária do Reino Unido 33 (Companies Act 2006). A “visão justa e verdadeira” (true and fair view) é um pilar conceitual incorporado ao ambiente de regulação contábil do Reino Unido há muitas décadas. $^{34}$

Para aplicação do método contábil da fusão, os seguintes procedimentos devem ser observados:

(1) ativos e passivos das partes envolvidas na combinação não são requeridos para serem mensurados ao valor justo, devendo permanecer por seus valores contábeis registrados

"Historically, FRS 6 stated 'acquisition accounting would require the restatement at fair value of the assets and liabilities of the company transferred, and the recognizing of goodwill, which is likely to be inappropriate in the case of a transaction that does not alter the relative rights of the ultimate shareholders' [FRS 6.78], and this sentence in FRS 6 was used as support for the argument that application of acquisition accounting was unlikely to give a true and fair view" (THE FINANCIAL REPORTING GROUP OF EY, 2017, p. 951).

"While FRS 102 contains no such health warning, the position is likely to remain the same that, in certain circumstances, notwithstanding that it is permitted (or required, where the strict criteria of merger accounting are not met) by company law and FRS 102, the application of the purchase method and all entails would not be appropriate, and that a 'true and fair override' to apply the merger accounting method may be necessary” (THE FINANCIAL REPORTING GROUP OF EY, 2017, p. 951).

"It will be evident from the above that the FRC expects preparers, those charged with governance and auditors to use the true and fair override where compliance with the standards does not result in the presentation of a true and fair view" (FRS - True and Fair Statement, June 2014, p. 6, grifo nosso).

"The directors of a company must not approve accounts for the purposes of this Chapter unless they are satisfied that they give a true and fair view of the assets, liabilities, financial position and profit or loss" (Companies Act 2006, Section 393, “Annual Accounts”).

34 Disponível em: https://www.icaew.com/-/media/corporate/archive/files/members/local-support-and-services/local-groups-and-societies/frc-reaffirms-the-primacy-of-the-true-and-fair-view-concept-but-why.ashx. Acesso em: 19 dez. 2019. 
(carrying values), muito embora ajustes para alcançar a uniformidade de práticas contábeis devam ser efetivados;

(2) resultados e fluxos de caixa das entidades combinadas devem ser apresentados nas demonstrações contábeis resultantes a partir do início do exercício social de ocorrência da combinação, ajustados para alcançar uniformidade das práticas contábeis;

(3) informações comparativas devem ser reapresentadas para inclusão do resultado abrangente de todas as entidades combinadas, para o período anterior à combinação, assim como os balanços patrimoniais, ambos ajustados para alcançar uniformidade das práticas contábeis;

(4) eventual diferença, se houver, entre o valor nominal das ações emitidas acrescido do valor justo de qualquer outra contraprestação dada em troca e o valor nominal das ações recebidas deve ser evidenciada como um movimento em outras reservas nas demonstrações contábeis consolidadas. Qualquer saldo existente em rubricas da "nova controlada" em prêmio de emissão de ações (share premium account) ou em reserva para resgate de capital (capital redemption reserve) deve ser evidenciado como um movimento em outras reservas ${ }^{35}$ também. Esses movimentos devem ser apresentados na demonstração de mutação do PL;

(5) despesas com a combinação não devem ser incluídas como parte dos ajustes referidos, ${ }^{\mathbf{3 6}}$ mas devem ser reconhecidas em demonstração de resultado abrangente como item integrante de lucro ou prejuízo da entidade combinada, na data efetiva da reestruturação do grupo.

Algumas considerações devem ser tecidas acerca dos procedimentos a serem observados quando da adoção do método contábil da fusão. A primeira diz respeito ao valor contábil de ativos e passivos das empresas combinadas. Não há uma prescrição específica para aplicação do pushdown accounting na regulação do Reino Unido, e a bem da verdade a lei societária do Reino Unido é categórica ao afirmar que os números devem ser reportados pelos valores reconhecidos nas demonstrações contábeis da companhia adquirida quando da adoção do método

35 "This is because they do not relate to the share capital of the reporting entity. Again, this difference should be shown in the statement of changes in equity. Such a difference should probably be taken to the same reserve as that on the elimination of the share capital of the subsidiary, because in reality the distinction between share capital and share premium can be seen to be arbitrary in this context” (THE FINANCIAL REPORTING GROUP OF EY, 2017, p. 956-957).

Entretanto, gastos associados com a emissão de ações na reestruturação podem ser compensados com eventuais prêmios ou recursos captados, refletindo uma captação líquida de custos. 
contábil da fusão. ${ }^{37}$ Por outro lado, a prática profissional entende ser mais apropriada, e ser considerada uma informação de maior relevância, a adoção do pushdown accounting. ${ }^{\mathbf{3 8}}$

A segunda consideração está relacionada com as informações comparativas. Aqui há um aparente conflito entre a prática profissional e a lei societária do Reino Unido. Esta requer que para aplicação do merger accounting sejam apresentadas informações comparativas do período anterior, englobando resultados, fluxos de caixa e posição financeira das entidades combinadas (Schedule 6, Group Accounts, $\$ \$ 11.3$ e 11.4).

Entretanto, caso o controle final das companhias combinadas tenha sido transferido para o atual controlador comum após o início do exercício social anterior ao exercício atual de ocorrência da transação sob controle comum, o entendimento esposado pela prática profissional, pela interpretação do dispositivo legal, é o de que resultados e fluxos de caixa comparativos devem ser consolidados a partir dessa data (em que as entidades passaram a ficar sob controle comum). ${ }^{39}$ E a própria prática profissional deve ser observada para fins de adoção do merger accounting, conforme disposição legal.

Outro ponto associado às informações comparativas reside em como tratar as ações emitidas pela companhia emissora na reestruturação de grupo ("adquirente”), que é a companhia que reporta, quando a subsidiária integral do grupo, adquirida no período corrente da operação, é considerada como se já fosse integrante do atual arranjo societário, no início do período comparativo. As ações emitidas pela companhia que reporta são consideradas como se tivessem sido emitidas no início do período comparativo.

Contudo, caso a subsidiária integral adquirida tenha emitido ações entre o início do período comparativo e a data da reestruturação de grupo, as ações emitidas pela companhia emissora na reestruturação de grupo (“adquirente”), em montante equivalente pelo seu valor

"The conditions for accounting for an acquisition as a merger are that adoption of the merger method of accounting accords with generally accepted accounting principles or practice (Schedule 6, 'Group Accounts', $\S 10)$. The assets and liabilities of the undertaking acquired must be brought into the group accounts at the figures at which they stand in the undertaking's accounts, subject to any adjustment authorised or required by this Schedule" (Schedule 6, "Group Accounts”, §11.2, grifos nossos).

38 "Using the carrying values reported in the financial statements of the transferred entity is more straightforward. [...]. However, where the transferred entity had been previously acquired by the parent, using the carrying values (including any fair value adjustments and goodwill arising on that acquisition) reported in the consolidated financial statements of the parent may be more appropriate. This results in the assets and liabilities being reported on the same basis as if the transferred entity had been acquired by the reporting entity at the time the transferred entity was acquired by the parent, and could be considered to provide information that may be more relevant to the parent" (THE FINANCIAL REPORTING GROUP OF EY, 2017, p. 955, grifos nossos).

The Financial Reporting Group of Ey (2017, p. 955, item 5.3.2). E também no UK Accounting Consulting Services of PWC (2013, p. 19046, item 19.174). 
nominal, serão tratadas como se tivessem sido emitidas na data de emissão das ações da subsidiária adquirida (com as devidas evidenciações na Demonstração das Mutações do Patrimônio Líquido - DMPL).

Se a companhia que reporta tiver dado outra contraprestação para levar a efeito a reestruturação do grupo, por exemplo caixa e/ou passivo intragrupo, a prática contábil oferece duas escolhas para refletir a operação nas demonstrações consolidadas. Considerar o passivo intragrupo como se já existisse no início do período comparativo, e nesse caso ajustado a valor presente (com todos os desdobramentos em resultado - DRE - da passagem do tempo), ou apresentá-lo tão somente na data de efetivação da reestruturação do grupo.

Por fim, a terceira e última consideração diz respeito às eliminações no balanço consolidado da participação detida (rubrica de investimento) contra o patrimônio líquido das controladas combinadas. Pelo método contábil da fusão, as ações emitidas pela companhia que exerce a função de “adquirente” em uma reestruturação de grupo devem ter seu valor de troca pelo seu valor nominal, em vez de pelo seu valor justo. E nesse particular podem surgir diferenças na eliminação, para cima ou para baixo, com repercussão na legislação societária do Reino Unido.

A lei societária do Reino Unido oferece poucas alternativas para emissão de ações por um valor diferente do seu valor justo, em circunstâncias restritas, que impliquem o não reconhecimento de um prêmio de emissão (diferença entre o valor nominal e o valor justo da ação). De acordo com disposições legais, esse prêmio de emissão é reconhecido em uma reserva de capital (share premium account), com usos bem específicos. É considerado parte do capital social. E o princípio que inspira referida salvaguarda na legislação societária do Reino Unido é o da manutenção do capital (stringent rules on the maintenance of capital).

Essas situações específicas para emissão de ações por um valor diferente do seu valor justo dizem respeito à isenção de merger (merger relief - CA2006, Section 612) e à isenção de reestruturação de grupo (group reconstruction relief - CA2006, Section 611), introduzidas na legislação societária do Reino Unido no ano de 1981 como forma de possibilitar a aplicação do método contábil da fusão. ${ }^{40}$

Até a efetivação dessa emenda na lei, um leading case dos tribunais ingleses, documentado na literatura como "Shearer (Inspector of Taxes) versus Bercain Ltd.", julgado no ano de 1980, reforçou mais ainda o entendimento de que haveria a necessidade de reconhecimento de um prêmio

"[...] merger accounting is a form of financial reporting which applies to a group reconstruction which meet certain qualifying conditions, but although the merger relief provisions were originally brought in to facilitate merger accounting, merger relief is purely a legal matter to do with the maintenance of capital for the protection of creditors and has very little to do with accounting per se" (THE FINANCIAL REPORTING GROUP OF EY, 2017, p. 964, item 5.4.1). 
de emissão quando as ações emitidas fossem dadas em troca de ativos não caixa (non-cash assets).

\section{E essa decisão acabou por restringir a aplicação do método contábil da fusão.}

A companhia Bercain Ltd., uma subsidiária integral de um grupo controlado por uma holding, emitiu ações pelo seu valor nominal, em montante de 4.100 libras esterlinas, em troca de participações detidas pela holding do grupo em duas outras subsidiárias integrais, LT Ltd. e AS Ltd., respectivamente nos montantes de 84.000 libras esterlinas e 12.000 libras esterlinas. O excesso de valor das ações adquiridas pelas ações dadas em troca, no caso 91.900 libras esterlinas, foi destinado em parte para constituição de uma reserva de capital (share premium account), no montante de 91.717 libras esterlinas.

Ato contínuo, no final do exercício social, as companhias LT Ltd. e AS Ltd., cada qual, distribuíram, a título de dividendos, respectivamente 35.000 libras esterlinas e 1.050 libras esterlinas, provocando no balanço da companhia Bercain Ltd. um impacto de 36.050 libras esterlinas de redução da rubrica de investimento (em contrapartida ao caixa recebido). A reserva de capital (share premium account) no montante de 91.717 libras esterlinas serviu de lastro para distribuição reflexa de dividendos aos acionistas da companhia Bercain Ltd., em uma manobra que permitiu afastar a tributação.

O fiscal de imposto de renda inglês, de nome Shearer, com base no Income and Corporation Taxes Act 1970, autuou a companhia Bercain Ltd., glosou os lançamentos efetuados para reconhecimento dos dividendos distribuídos e exigiu a título de tributo sobre o lucro 10.819,80 libras esterlinas.

A questão foi levada aos Comissários Especiais de Tributo sobre a Renda, ${ }^{41}$ que entenderam que (i) o excesso de valor deveria ser destinado, como foi, para constituição de uma reserva de capital (share premium account); (ii) assim procedendo, a companhia Bercain Ltd., estaria impedida, nos termos da lei societária inglesa, de utilizar a reserva de capital (share premium account) para determinados fins, entre os quais a distribuição de dividendos; (iii) por se tratar de espécie do gênero capital (há uma obrigação implícita de capitalizar), a reserva de capital não estaria sujeita à tributação.

A Coroa Inglesa apelou da decisão dos Comissários Especiais de Tributo sobre a Renda à Alta Corte de Justiça Inglesa ${ }^{42}$ (High Court of Justice in England), que, ao julgar o recurso, manteve a decisão, entendendo que os Comissários Especiais chegaram a uma conclusão apropriada.

41 Os Comissários Especiais de Tributo sobre a Renda são indicados pela Secretaria do Tesouro Inglês e são apoiados administrativamente pela Receita Federal Inglesa. Eles desempenham a função de tribunal administrativo de apelação em matéria de tributos e constituem-se em um corpo independente, dedicado exclusivamente ao desempenho da função. De suas decisões cabe recurso à Alta Corte Inglesa, tanto por parte de contribuintes quanto por parte da Coroa Inglesa.

42 A Alta Corte de Justiça Inglesa compõe, juntamente com a Corte de Apelação e a Corte da Coroa Inglesa, uma das Altas Cortes da Inglaterra e do País de Gales. A Alta Corte de Justiça Inglesa trata de casos de 
Prosseguindo no estudo da lei societária do Reino Unido (CA 2006), em particular as disposições voltadas à rubrica de prêmio na emissão de ações, sejam essas ações integralizadas ou dadas em troca de dinheiro (cash) ou de ativos de outra natureza (non-cash), a lei é categórica ao determinar que o montante agregado do prêmio deve ser transferido para uma conta denominada the share premium account, que somente pode ser utilizada para: (i) confronto com despesas e comissões advindas da emissão (captação líquida dos custos associados), (ii) distribuição de novas ações aos acionistas da companhia (via sua capitalização) e (iii) redução de capital social ${ }^{43}$ (via seu consumo).

Para fugir da obrigatoriedade de emitir ações ao valor justo e do dever de reconhecer o prêmio observado em uma reserva de capital (the share premium account), a administração da companhia precisa saber qual isenção legal aplicar - visto que são mutuamente excludentes - quando da adoção de método contábil da fusão, ${ }^{44}$ se no caso deve ser aplicada a isenção de merger (CA 2006, Section 612) ou a isenção de reestruturação de grupo (CA 2006, Section 611). Há que se identificar que tipo de arranjo societário está sendo efetivado. ${ }^{45}$

Para isenção de reestruturação de grupo, a lei societária inglesa requer que sejam observadas as seguintes condições:

(i) a companhia emissora deve ser uma subsidiária integral de outra companhia (holding company);

(ii) as ações emitidas pela companhia emissora (identificada como "adquirente") devem ser distribuídas para a companhia holding ou para outra subsidiária integral da companhia holding, em contraprestação à transferência para companhia emissora de ativos não caixa (non-cash assets) da companhia que é integrante do grupo de companhias (the transferor company), grupo esse que compreende a companhia holding e suas subsidiárias integrais;

(iii) quando as ações emitidas pela companhia emissora (“adquirente”), distribuídas em contraprestação pelos ativos transferidos, forem emitidas com um prêmio, a companhia emissora não deve ser obrigada legalmente a transferir qualquer excedente ao valor

grande importância e complexidade, e também exerce uma supervisão jurisdicional sobre todas as cortes e tribunais ingleses e galeses, com poucas exceções estatutárias.

43 "The provisions of the Companies Act relating to the reduction of a company's share capital apply as if the share premium account were part of its paid up share capital” (CA 2006, Section 610, Subsection 4).

44 Possibilitará com isso a emissão de ações da companhia identificada como adquirente na reestruturação do grupo pelo seu valor nominal, caso a operação seja liquidada, em parte ou no seu todo, em ações de própria emissão.

Vide esquema gráfico elucidativo no Anexo 4 deste artigo. 
de prêmio mínimo para a rubrica de share premium account (não aplicação do CA 2006, Section 610);

(iv) no caso do prêmio mínimo, este é resultado do excesso observado entre o valor base da contraprestação dada em troca na reestruturação e o valor nominal das ações distribuídas. É um expediente contábil para acertar as eliminações no consolidado. Esse prêmio mínimo não está sujeito a isenção. Deverá ser reconhecido contabilmente na rubrica de share premium account.

O valor base da contraprestação dada em troca na reestruturação é o montante pelo qual o valor base dos ativos transferidos excede o valor base de quaisquer passivos transferidos assumidos pela companhia emissora na reestruturação. E o valor base dos ativos transferidos é obtido por meio do custo de referidos ativos para a companhia que os transfere (transferor company) ou, se inferior, pelo montante pelo qual referidos ativos estavam apresentados nos registros contábeis da companhia que os transfere, imediatamente antes da transferência (caso estejam registrados por valores reavaliados ou pelo MEP). Já o valor base dos passivos transferidos assumidos é o montante pelo qual estavam apresentados nos registros contábeis da companhia que os transfere, imediatamente antes da transferência.

Já para isenção de merger, a lei societária inglesa requer que sejam observadas as seguintes condições:

(i) a companhia emissora ("adquirente") deve obter, no mínimo, $90 \%$ das ações ${ }^{46}$ de outra companhia do grupo, em consequência de um arranjo societário que possibilite a distribuição de ações de sua própria emissão em troca da emissão ou transferência das ações de outra companhia do grupo (transferor company), ou do cancelamento de ditas ações, não detidas pela companhia emissora;

(ii) quando as ações emitidas pela companhia emissora (“adquirente”), distribuídas em contraprestação pelas ações transferidas ou canceladas de outra companhia do grupo,

46 Esse patamar de $90 \%$ pode ser alcançado em uma única operação ou em operações sucessivas, contempladas ou não no arranjo societário. Contudo, a isenção poderá ser aplicada parcialmente. Por exemplo, se a companhia emissora ("adquirente") obtém, em troca de suas ações emitidas ao par, 15\% das ações de outra companhia do grupo (transferor company), em uma transação isolada e não associada a transações subsequentes, e 15 anos depois obtém mais 75\% das ações, alcançando com isso o threshold de 90\% requerido, a isenção será aplicada tão somente para $75 \%$ das ações. Por outro lado, caso esteja prevista uma operação de obtenção de lotes sucessivos de 30\% das ações (partial acquisitions), até alcançar o threshold de 90\%, a isenção deverá ser aplicada integralmente. 
forem emitidas com um prêmio, a companhia emissora não está obrigada a destinar tal prêmio para a rubrica de share premium account (não aplicação do CA 2006, Section 610);

(iii) a companhia do grupo que transfere seus títulos patrimoniais (transferor company) para a companhia emissora ("adquirente"), em troca de contraprestação recebida, pode emitir outros títulos patrimoniais que não sejam ações ${ }^{\mathbf{4 7}}$ (non-equity shares) ou cancelar esses outros títulos patrimoniais que não sejam detidos pela companhia emissora. Eventual prêmio de emissão observado na operação está isento da destinação para a rubrica de share premium account (não aplicação do CA 2006, Section 610);

(iv) não aplicação dessa isenção, quando houver enquadramento da operação na isenção de reestruturação de grupo.

Logo, o primeiro procedimento a levar a efeito para fins societários, quando da adoção do método contábil da fusão, é checar se a isenção aplicável é a de reestruturação de grupo. Não sendo, passa-se para aplicação da isenção de merger.

Assim, encerrando esta terceira e última consideração acerca de procedimentos a serem observados quando da adoção do método contábil da fusão, nas eliminações a serem feitas para elaboração do balanço consolidado, quando houver um saldo credor (o valor das ações ou dos ativos transferidos na operação superar o valor nominal das ações emitidas acrescido do valor justo de outras contraprestações), deverá ser constituída uma reserva de merger (evidenciada no BP e na DMPL) e ser aplicada uma das isenções previstas na lei societária para eventual prêmio observado.

Já quando houver saldo devedor (o valor das ações ou dos ativos recebidos na operação for superado pelo valor nominal das ações emitidas acrescido do valor justo de outras

47 A definição para non-equity shares é obtida na Section 616 da lei societária do Reino Unido. É toda participação de capital que não integra o capital social ("equity shares” means shares comprised in a company's equity share capital, and "non-equity shares" means shares - of any class - that are not so comprised). Maiores elucidações são obtidas de um antigo UKGAAP, anterior ao FRS n. 102, que trata de instrumentos de capital, o FRS n. 4. Non-equity shares são participações que possuem uma das seguintes características: (i) qualquer direito de participação a recebimentos (seja por dividendos, por resgate ou por outra forma) é limitado a um montante, que não é calculado tendo como referência ativos ou lucros da companhia ou dividendos de qualquer classe de ação; (ii) qualquer direito de participação em um excedente de liquidação (surplus in a winding up) é limitado a um montante específico, que não é calculado tendo como referência ativos ou lucros da companhia, e referida limitação tem efeito comercial prático no momento em que as participações são emitidas ou, se posterior, no momento em que a limitação é introduzida; ou (iii) as participações são resgatadas conforme disposições contratuais ou por vontade do titular ou de qualquer outra parte que não seja o emissor. 
contraprestações), há uma lacuna na legislação societária e falta de previsão na FRS n. 102. O que a prática profissional vem fazendo é eliminá-lo contra as reservas de categorias mais restritivas (o que implica considerar somente as reservas de lucros realizados, excluindo desse rol saldos de outros resultados abrangentes) e, remanescendo saldo, eliminá-lo contra lucros acumulados.

Até aqui, tudo o que foi tratado em matéria de método contábil da fusão está voltado às demonstrações consolidadas. Para as demonstrações individuais, a prática contábil oferece algumas orientações, visto que o FRS n. 102 é silente quanto ao tratamento a ser dispensado. E problemas surgem para a contabilização adequada de transações sob controle comum envolvendo ativos negociáveis (trade assets) ou ativos líquidos (net assets) de outra entidade do grupo, as já definidas e mencionadas transações hive across e hive down.

Nesse particular, soluções para os problemas de tratamento são fornecidas pelo Statement of Recommended Practice (SORP) para adoção dos FRSs n. 100, 101 e 102, emitido pelo CCAB,${ }^{48}$ e pelo TECH n. 02/2010, emitido pelo ICAEW em conjunto com o ICAS.

Uma primeira questão reside na forma de apresentar os lucros acumulados "pré-transação" de negócios sob controle comum adquiridos. Ilustrando o problema, caso uma nova companhia holding intermediária Y do grupo seja constituída em 01.05.20X1, e ato contínuo sejam para ela transferidas participações em duas outras controladas sob controle comum, Alfa e Beta, já existentes e em plena operação, como seriam tratados os lucros "pré-transação” das controladas Alfa e Beta, no período de 01.01.20X1 a 30.04.20X1, nas demonstrações contábeis de Y?

O método contábil da fusão requer que os resultados e os fluxos de caixa das entidades combinadas sejam apresentados nas demonstrações contábeis resultantes, a partir do início do exercício social de ocorrência da combinação. Entretanto, essa regra para demonstrações individuais encontra óbices legais. A lei societária do Reino Unido estabelece que

48 Conforme descrito no site do the Consultative Committee of Accountancy Bodies (CCAB) (Disponível em: https://www.ccab.org.uk/. Acesso em: 5 nov. 2020) -, o organismo foi criado com a missão central de promover o crescimento sustentável no Reino Unido por meio da profissão contábil. É formado pelas seguintes entidades: the Institute of Chartered Accountants in England and Wales (ICAEW) (Disponível em: https://www.icaew.com/. Acesso em: 5 nov. 2020), the Association of Chartered Certified Accountants (ACCA) (Disponível em: https://www.accaglobal.com/gb/en.html. Acesso em: 5 nov. 2020), the Chartered Institute of Public, Finance and Accountancy (CIPFA) (Disponível em: https:// www.cipfa.org/. Acesso em: 5 nov. 2020), the Institute of Chartered Accountants of Scotland (ICAS) (Disponível em: https://www.icas.com/. Acesso em: 5 nov. 2020) e Chartered Accountants of Ireland (Disponível em: https://www.charteredaccountants.ie/. Acesso em: 5 nov. 2020). Segundo informações do CCAB, a profissão contábil contribui com 15\% do PIB do Reino Unido (a cada ano, 166 bilhões de libras esterlinas). 
somente os lucros realizados sejam apresentados pela entidade que reporta em sua DRE individual, conforme salientado no Apêndice do FRS n. 102.49

Três são as escolhas contábeis possíveis, propostas pela prática contábil. A primeira abordagem considera que os lucros acumulados "pré-transação" do negócio adquirido, caso estejam realizados, muito embora não sejam lucros realizados da entidade que reporta, podem ser incluídos na DRE individual resultante da combinação, a partir do início do exercício social em que a combinação é efetivada (aplicando na íntegra o merger accounting method), contanto que sejam transferidos para uma reserva não distribuível do PL individual.

A segunda abordagem é incluí-los - os lucros acumulados "pré-transação" - na DRE pós-transação, a partir do início do exercício social em que a transação é efetivada (aplicando na íntegra o merger accounting method), dando o devido disclosure em nota explicativa e segregando na informação em nota o que é lucro realizado da entidade que reporta e o que não é.

Por fim, a terceira e última abordagem, a recomendada pelo SORP para adoção dos FRSs n. 100, 101 e 102, pelo seu alinhamento com a lei societária do Reino Unido, e endossada pelo FRC, ${ }^{50}$ é aplicar parcialmente o merger accounting method, ou seja, de modo prospectivo, incluindo na DRE pós-transação somente os lucros do negócio adquirido, a partir da data da transação. Uma demonstração pro forma com os lucros de todo o exercício do negócio adquirido (desde o início do exercício), inclusive com informações comparativas, poderá ser apresentada de modo suplementar em nota explicativa, caso a companhia que reporta deseje evidenciar os resultados de seus negócios subjacentes.

Prosseguindo com o tratamento do merger accounting method nas demonstrações individuais, outro ponto surge na eliminação dos efeitos da transação com ativos negociáveis (trade assets) ou ativos líquidos (net assets) de outra entidade do grupo. Não há PL de uma companhia "adquirida" contra o qual possa ser eliminado o excesso de custo incorrido na transação (valor nominal das ações emitidas pela companhia emissora - "adquirente" - acrescido do valor justo de outras contraprestações em excesso ao custo dos ativos transferidos).

A solução é seguir a regra do consolidado, via eliminação no patrimônio líquido, em uma rubrica de reserva. Não há uma diretriz normativa ou legal nesse sentido. É a prática contábil que dá a diretriz por meio do TECH n. 02/2010 - Guidance on the Determination of Realised Pro-

fits and Losses in the Context of Distributions under the Companies Act 2006. Cabe reproduzir a seguir os $\S 9.36$ e 9.37 da TECH n. 02/2010.

"Paragraph 13(a) of Schedule 1 to the Regulations requires that only profits realised at the reporting date are included in profit or loss, a requirement modified from that in Article 31.1(c)(aa) of the Fourth Directive which refers to profits 'made' at the balance sheet date" (FRS n. 102, Appendix IV, §A4.25).

50 "The FRC has concluded that the SORP does not contain any fundamental points of principle that are unacceptable in the context of present accounting practices or to conflict with an accounting standard" (THE FINANCIAL REPORTING GROUP OF EY, 2017, p. 960, item 5.3.6.A). 
Quando uma companhia leva a efeito uma transação sob controle comum, como por exemplo a aquisição de um negócio de outra companhia dentro do mesmo grupo, seus diretores podem julgar não ser apropriado reconhecer os ativos líquidos adquiridos pelos seus valores justos e não ser apropriado reconhecer "goodwill". Por exemplo, uma companhia pode comprar os ativos de uma linha de negócios de sua companhia controladora, sendo dado como contraprestação por essa transferência uma combinação de ações emitidas com o caixa da companhia. Os diretores podem julgar como mais apropriado reconhecer os ativos líquidos pelo montante que estavam reconhecidos nas demonstrações financeiras da companhia alienante.

A contraprestação dada em troca, representada pelo valor nominal das ações emitidas acrescido do montante de caixa transferido, pode exceder o valor de livros dos ativos adquiridos e isso pode resultar em uma diferença a ser reconhecida por um débito. Isso não é goodwill. O débito por vezes é tratado como uma diferença de merger e é reconhecido no patrimônio líquido. ${ }^{\mathbf{5 1}}$ (tradução livre, grifos nossos)

Uma combinação de negócios envolvendo entidades integrantes de um mesmo grupo é ultimada sob a direção de uma entidade controladora, o controlador comum. Consequentemente, qualquer pagamento do adquirente em excesso ao valor de livros dos ativos líquidos do vendedor é tratado contabilmente de maneira similar a uma distribuição ou devolução de capital para o controlador comum. Distribuições e devoluções de capital são tratadas dentro do patrimônio líquido, e, portanto, é também lógico reconhecer o débito no patrimônio líquido.$^{\mathbf{5 2}}$ (tradução livre, grifos nossos)

Como se observa, a prática contábil do Reino Unido encara as transações sob controle comum como se fossem distribuições ou contribuições de capital, razão pela qual há uma

"When a company carries out a transaction under common control such as acquiring the business of another company within the same group, the directors may determine that it is not appropriate to recognise the net assets acquired at their fair values and that it is not appropriate to recognise goodwill. For example, a company may purchase the trade and assets of a division from its parent company, the consideration being a combination of cash and shares. The directors may determine that the appropriate accounting is to recognise the net assets acquired at the transferor's book amounts. The consideration paid, say, measured at the nominal value of the shares issued plus the value of the cash element, may exceed the book amount of the net assets acquired and this will leave a debit difference to be recognised. It is not goodwill. The debit is sometimes referred to as a 'merger difference' and is recorded in equity” (TECH 02/2010.9.36).

"A business combination involving members of the same group is completed under the direction of the controlling party, the common parent. Consequently, any excess paid by the acquirer over the book amount of the vendor's net assets is accounted for in a similar manner to a distribution or return of capital to the common parent. Distributions and returns of capital are dealt with through equity, and therefore it is logical also to recognise the debit in equity" (TECH 02/2010.9.37). 
orientação específica para identificação de lucros realizados ou não nessas operações (o documento TECH n. 02/2010). Até para saber como encarar os ajustes a débito no patrimônio líquido; se como distribuições de capital ou não.

O débito reconhecido no patrimônio líquido só será considerado uma distribuição nos termos da lei caso a companhia "adquirente" ofereça outra contraprestação ao valor justo, que não sejam ações de própria emissão pelo seu valor nominal, em excesso ao valor justo dos ativos para ela transferidos. Esse excesso poderá compor parte de uma distribuição corrente, conforme elucidado pelo TECH n. 02/2010, §9.38.

Por outro lado, quando a contraprestação pelos ativos transferidos a valor de livros se der unicamente com ações de emissão da companhia "adquirente" pelo seu valor nominal, o débito no patrimônio líquido irá refletir o quanto de contraprestação superou o valor pelo qual os ativos adquiridos estavam registrados na companhia que os transfere. E esse número não representa uma distribuição e tampouco uma perda na sua totalidade, seja ela realizada ou não realizada. Ele poderá vir a se tornar uma perda realizada no futuro, também conforme elucidado pelo TECH n. 02 /2010, em seu $§ 9.39$.

É o caso, por exemplo, de os ativos transferidos sofrerem subsequentemente perdas por impairment (goodwill e/ ou ativo imobilizado), ou terem sido transferidos por valor contábil superior ao valor de recuperação, ou ainda sofrerem depreciação ou amortização subsequentemente pelo seu consumo ao longo de sua vida útil. Nessas circunstâncias, a perda será considerada realizada, segundo orientação do TECH n. 02/2010, em seu $§ 9.40$, em linha com os princípios de realização discutidos na seção 3 do referido documento.

Encerrando esta seção, poderá ocorrer também, assim como já discutido para o consolidado, um ajuste a crédito no patrimônio líquido. Se referido crédito será tratado em uma reserva em separado, sob denominação de uma reserva de merger, ou como integrante de rubrica de lucros acumulados, irá depender da abordagem adotada para os lucros acumulados “pré-transação”. O Tech n. 02/2010, em seus $\$ \S 3.18^{53}$ e 3.18a, ${ }^{\mathbf{5 4}}$ orienta para que seja adotada a abordagem top-slicing para identificação de lucros realizados nas trocas de ativos.

53 "Where an asset is sold partly for qualifying consideration and partly for other consideration (for example, a mixed consideration of cash and a freehold property), any profit arising is a realised profit to the extent that the fair value of the consideration received is in the form of qualifying consideration. This approach is sometimes referred to as 'top-slicing'. (Example: fair value of consideration received is $£ 10 \mathrm{~m}$, of which $£ 4 \mathrm{~m}$ is cash and $£ 6 \mathrm{~m}$ is freehold property. If the depreciated historical cost of the asset sold is $£ 5 \mathrm{~m}$, the total gain is $£ 5 \mathrm{~m}$ but the realised profit is limited to $£ 4 \mathrm{~m}$. .)” (TECH $02 / 2010.3 .18$ ).

54 "The consideration received may comprise a combination of assets and liabilities. For example, this will often be the case on a transfer of trade and assets for no consideration (eg, a 'hive down' or 'hive across'). To apply the 'top slicing' rule in this case, any liabilities should first be deducted from the amount of qualifying consideration received. The profit will be realised only to the extent of any net balance of qualifying consideration received. For example, if a capital contribution received comprises investment property of $£ 100,000$ 


\section{Simulações}

A fim de ilustrar a aplicação das normas USGAAP e UKGAAP até aqui estudadas para as BCUCCs é desenvolvido a seguir um exercício. A repercussão da aplicação dessas normas no campo jurídico societário e tributário ocorre por meio de uma política contábil elaborada, para suprir lacuna da regulação contábil, nos termos do pronunciamento CPC n. 23 (IAS n. 8).

Sejam admitidas duas companhias, "A" e "B", com controladores distintos, "P1" e "P2", e com participações de não controladores, conforme Gráfico 1, a seguir.

\section{GRÁFICO 1 - ESTRUTURAS SOCIETÁRIAS DAS COMPANHIAS "PI " E "P2"}
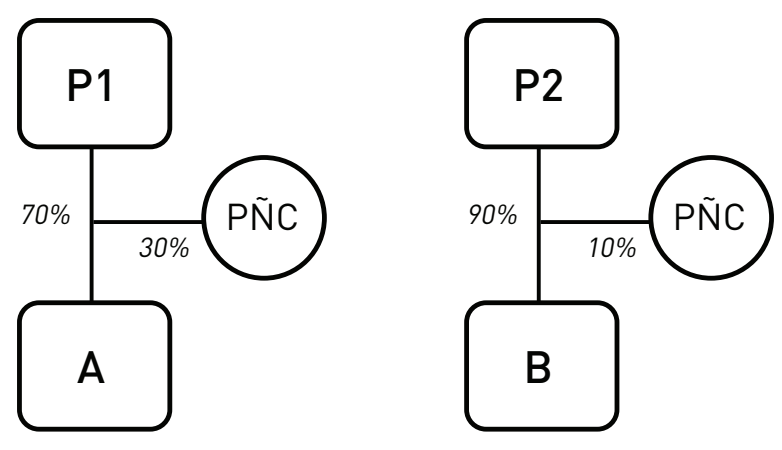

Fonte: Elaboração do autor.

Suas configurações patrimoniais iniciais são apresentadas na Tabela 1.

tabela 1 - CONFigurações Patrimoniais iniciais de “A” E “B”

\begin{tabular}{|c|c|c|c|c|c|}
\hline & P1 & A & Débito & Crédito & Consolidado \\
\hline caixa & 80,00 & 60,00 & & & 140,00 \\
\hline imobilizado & 120,00 & 40,00 & & & 160,00 \\
\hline Inv. A & 70,00 & & & 70,00 & \\
\hline Total & 270,00 & $\overline{100,00}$ & & & 300,00 \\
\hline $\begin{array}{r}P L \\
\text { capital }\end{array}$ & 2700 & 100,00 & 100,00 & & 270, \\
\hline PÑC & & & & 30,00 & 30,00 \\
\hline Total & 270,00 & 100,00 & $\overline{100,00}$ & $\overline{100,00}$ & 300,00 \\
\hline
\end{tabular}

(continua)

and cash of $£ 50,000$ together with a bank loan of $£ 70,000$, none of the resulting profit of $£ 80,000$ is realised because the net amount of qualifying consideration received is negative" (TECH 02/2010.3.18A). 


\begin{tabular}{|c|c|c|c|c|c|}
\hline & P2 & B & Débito & Crédito & Consolidado \\
\hline caixa & 30,00 & 6,00 & & & 36,00 \\
\hline estoques & - & 20,00 & & & 20,00 \\
\hline Inv. B & 23,40 & - & & 23,40 & \\
\hline Total & 53,40 & 26,00 & & & 56,00 \\
\hline \multicolumn{6}{|l|}{$\mathrm{PL}$} \\
\hline capital & 53,40 & 26,00 & 26,00 & & 53,40 \\
\hline PÑC & - & - & & 2,60 & 2,60 \\
\hline Total & 53,40 & 26,00 & $\overline{26,00}$ & 26,00 & 56,00 \\
\hline
\end{tabular}

Fonte: Elaboração do autor.

A distribuição de capital de cada qual é apresentada na Tabela 2.

TABEla 2 - DistribuiçÕes de CAPitAl DE “A” E "B”

\begin{tabular}{rrrr} 
& & \multicolumn{2}{c}{ Companhia "A" } \\
Acionista & Ações & VN & Capital \\
P1 & 70 & 1,00 & 70,00 \\
PÑ & 30 & 1,00 & 30,00 \\
\cline { 3 - 4 } & & & \\
& & & \\
& & \multicolumn{2}{c}{ Companhia "B" } \\
Acionista & Ações & VN & Capital \\
P2 & 18 & 1,30 & 23,40 \\
PÑC & 2 & 1,30 & 2,60 \\
\cline { 3 - 4 } & & & 26,00
\end{tabular}

Fonte: Elaboração do autor.

Seja admitido que ocorra uma combinação de negócios (genuína), por meio da qual a companhia P2 aliene o controle da companhia "B" para a companhia "P1" por \$50 e saia do negócio. A operação é liquidada em $\$ 40$ de caixa e um financiamento de $\$ 10$ em dívida. Para 
simplificação do exercício, ignoram-se os efeitos de uma Oferta Pública por Alienação de Controle (OPA) 254-A. ${ }^{55}$

A estrutura societária de "P1", após a combinação de negócios, passa a ser a que segue no Gráfico 2.

GRÁFICO 2 - ESTRUTURA SOCIETÁRIA DA COMPANHIA “P I” APÓS COMBINAÇÃO DE NEGÓCIOS

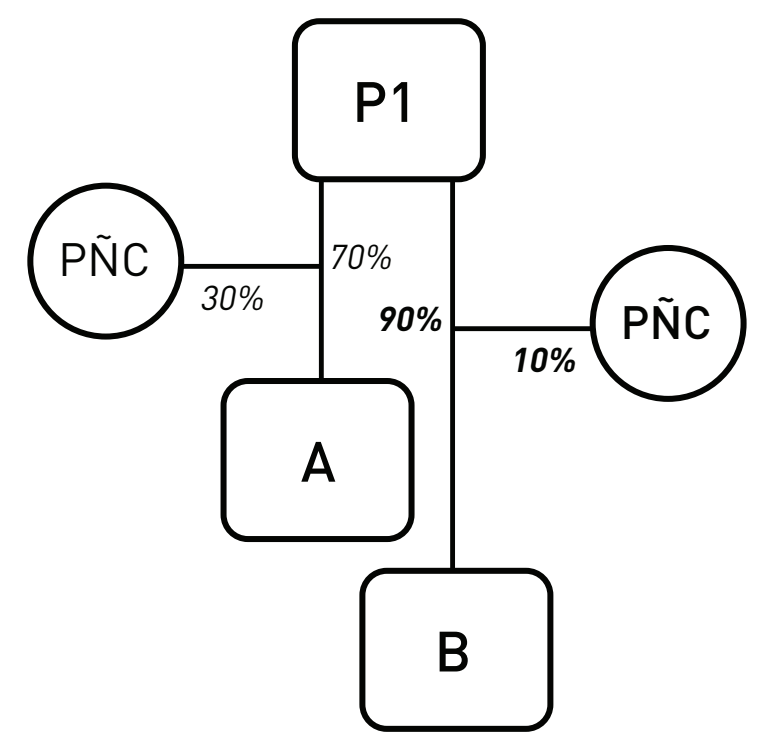

Fonte: Elaboração do autor.

Elaborando o Purchase Price Allocation (PPA) da operação, identifica-se um goodwill genuíno de $\$ 20,66$, conforme evidenciado na Tabela 3.

55 Lei n. 6.404/1976, art. 254-A. "A alienação, direta ou indireta, do controle de companhia aberta somente poderá ser contratada sob a condição, suspensiva ou resolutiva, de que o adquirente se obrigue a fazer oferta pública de aquisição das ações com direito a voto de propriedade dos demais acionistas da companhia, de modo a lhes assegurar o preço no mínimo igual a 80\% (oitenta por cento) do valor pago por ação com direito a voto, integrante do bloco de controle. [...] $\S 4^{\circ} \mathrm{O}$ adquirente do controle acionário de companhia aberta poderá oferecer aos acionistas minoritários a opção de permanecer na companhia, mediante o pagamento de um prêmio equivalente à diferença entre o valor de mercado das ações e o valor pago por ação integrante do bloco de controle”. 
TABELA 3 - PPA DA COMPANHIA 'B'

PPA:

Fair value contraprestação:

caixa $\quad 40,00$

$\begin{array}{lll}\text { dívida } & 10,00 & 50,00\end{array}$

Fair value PÑC (valor proporcional): $\quad 3,26$

Fair value ativos líquidos:

caixa

6,00

estoques

30,00

PFD - IRPJ E CSLL Diferidos

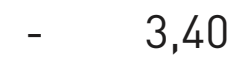

(34\% de alíquota)

32,60

Goodwill genuíno

20,66

Fonte: Elaboração do autor.

A configuração patrimonial de "P1" após a combinação é apresentada na Tabela 4.

TABEla 4 - CONFIGURAÇÃo PATRIMONiAL DE “P I’ APÓS COMBINAÇÃo DE NEGÓCIOS

\begin{tabular}{|c|c|c|c|c|c|c|}
\hline & P1 & A & B & Débito & \multicolumn{2}{|c|}{ Crédito Consolidado } \\
\hline caixa & 40,00 & 60,00 & 6,00 & & & 106,00 \\
\hline estoques & - & - & 20,00 & 10,00 & & 30,00 \\
\hline imobilizado & 120,00 & 40,00 & & & & 160,00 \\
\hline Inv. A & 70,00 & & & & 70,00 & - \\
\hline Inv. B & 50,00 & - & - & & 50,00 & - \\
\hline goodwill & & - & & 20,66 & & 20,66 \\
\hline Total & 280,00 & 100,00 & 26,00 & & & 316,66 \\
\hline PFD & & & & & 3,40 & 3,40 \\
\hline Empréstimo & 10,00 & & & & & 10,00 \\
\hline$P L$ & & & & & & - \\
\hline capital & 270,00 & 100,00 & 26,00 & 126,00 & & 270,00 \\
\hline PÑC & - & & - & & 33,26 & 33,26 \\
\hline Total & 280,00 & 100,00 & 26,00 & 156,66 & 156,66 & 316,66 \\
\hline
\end{tabular}

Fonte: Elaboração do autor. 
Já a distribuição de capital de “B” após a combinação é apresentada na Tabela 5.

\section{TABELA 5 - DisTRIBUIÇÃO DE CAPITAL DE “B” APÓS A COMBINAÇÃO DE NEGÓCIOS}

\begin{tabular}{rrrr} 
& & \multicolumn{2}{c}{ Companhia "B" } \\
Acionista & Ações & VN & Capital \\
P1 & 18 & 1,30 & 23,40 \\
PNC & 2 & 1,30 & 2,60 \\
\cline { 3 - 4 } & & & 26,00
\end{tabular}

Fonte: Elaboração do autor.

Ato contínuo, ocorre uma BCUCC. A companhia "B" passa a ser controlada diretamente por "A" e a ser controlada indiretamente por "P1". E seu controle continua sendo exercido por "P1", que é o controlador final na estrutura societária. A operação se efetiva mediante uma transferência de caixa de $\$ 55$ de "A" para "P1".

Considerando as alternativas oferecidas nas normas norte-americanas e nas normas do Reino Unido, quatro serão os modelos a serem trabalhados: predecessor sem pushdown, predecessor com pushdown, fair value sem pushdown e fair value com pushdown. Em todas as situações, a liquidação da BCUCC ocorrerá por meio de entrega de caixa (documentada na literatura como uma cash settlement transaction).

Para o caso de a liquidação ocorrer por meio de entrega de ações de própria emissão (documentada na literatura como uma stock-for-stock transaction), arranjos tributários sofisticados podem ser implementados no Brasil, conforme já documentado na literatura. ${ }^{\mathbf{5 6}}$

Desse modo, a estrutura societária de "P1", após a BCUCC, passa a ser a que segue no Gráfico 3.

56 Costa Junior (2019). 


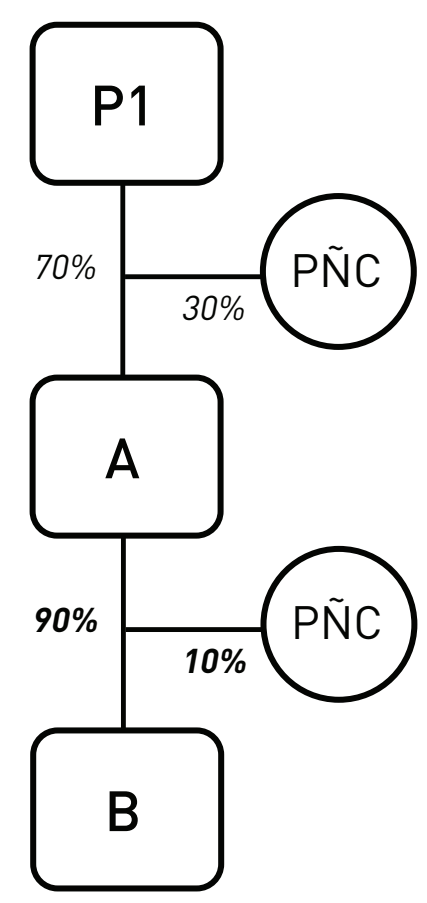

Fonte: Elaboração do autor.

\section{I. BCUCC PELO PREDECESSOR SEM PUSHDOWN}

O predecessor é um método requerido nos USGAAP para as BCUCC e admitido pelos UKGAAP. Essas questões foram abordadas na seção 1.

Desse modo, procedendo-se ao PPA ${ }^{57}$ da BCUCC, identifica-se um goodwill gerado internamente de $\$ 5,00$, conforme evidenciado na Tabela 6.

57 O PPA, a rigor, deve ser empregado quando da adoção do método da compra (fair value). O seu uso no exemplo tem o condão de identificar, para fins didáticos, o resíduo do preço alocado aos ativos líquidos transferidos. 
TABELA 6 - PPA DA COMPANHIA “B” APÓS BCUCC

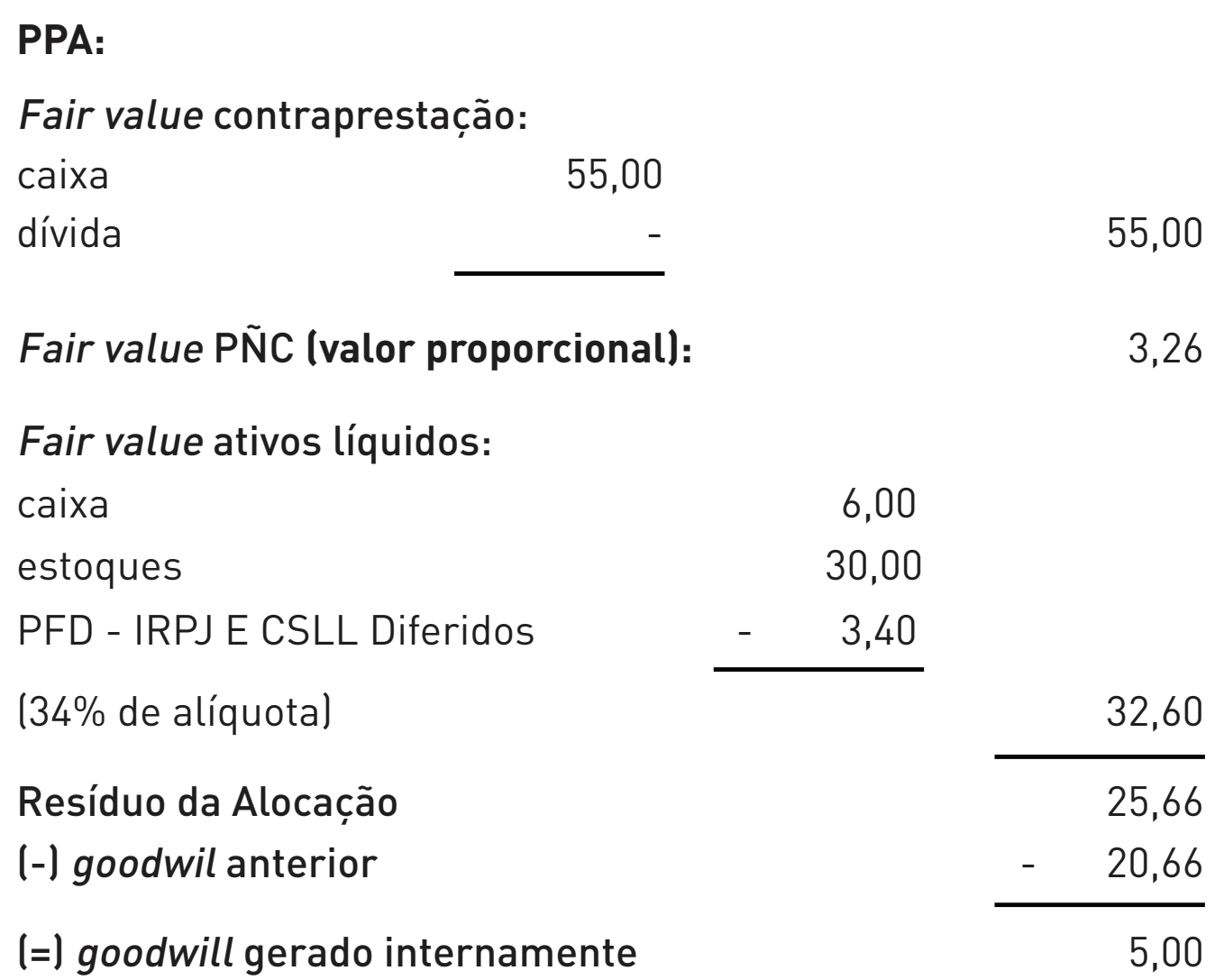

Fonte: Elaboração do autor.

Esses \$5 são justamente o caixa marginal que foi transferido entre empresas na BCUCC (da companhia "A" para "P1" quando da liquidação financeira da operação). Em essência, uma devolução de capital, conforme enxergado pela regulação contábil norte-americana e do Reino Unido. E, na essência, o controlador está levando a sua parte no caixa de "A" de $\$ 3,50(70 \%$ de $\$ 5,00)$, origem desses recursos, e mais a parte de não controladores de "A" de $\$ 1,50$ (30\% de $\$ 5,00)$. Essa informação ficará mais evidente com a apresentação das demonstrações contábeis individuais de "P1" e consolidadas.

Recapitulando, tanto a regulação contábil norte-americana quanto a do Reino Unido requerem que os efeitos de uma BCUCC sejam tratados no PL, e assim será procedido tanto nas demonstrações contábeis individuais quanto nas consolidadas. Os efeitos serão registrados em rubrica de reserva de capital, ${ }^{58}$ similar à paid-in capital reserve dos norte-americanos e à share premium account do Reino Unido. Para a realidade do Reino Unido, valores negativos são

58 As reservas de capital têm um uso bem delimitado pela Lei n. 6.404/1976. Em seu art. 13, § 2º será destinada à constituição da reserva a contribuição do subscritor que ultrapassar o valor nominal das ações subscritas; no art. 14, parágrafo único, para as ações sem valor nominal, será destinada à constituição da 
reconhecidos em reserva de lucros realizados ou em rubrica de lucros acumulados, conforme tratado na seção 1 .

Assim, a configuração patrimonial das companhias envolvidas após a BCUCC é apresentada na Tabela 7.

\section{TABELA 7 - BCUCC PELO PREDECESSOR SEM PUSHDOWN}

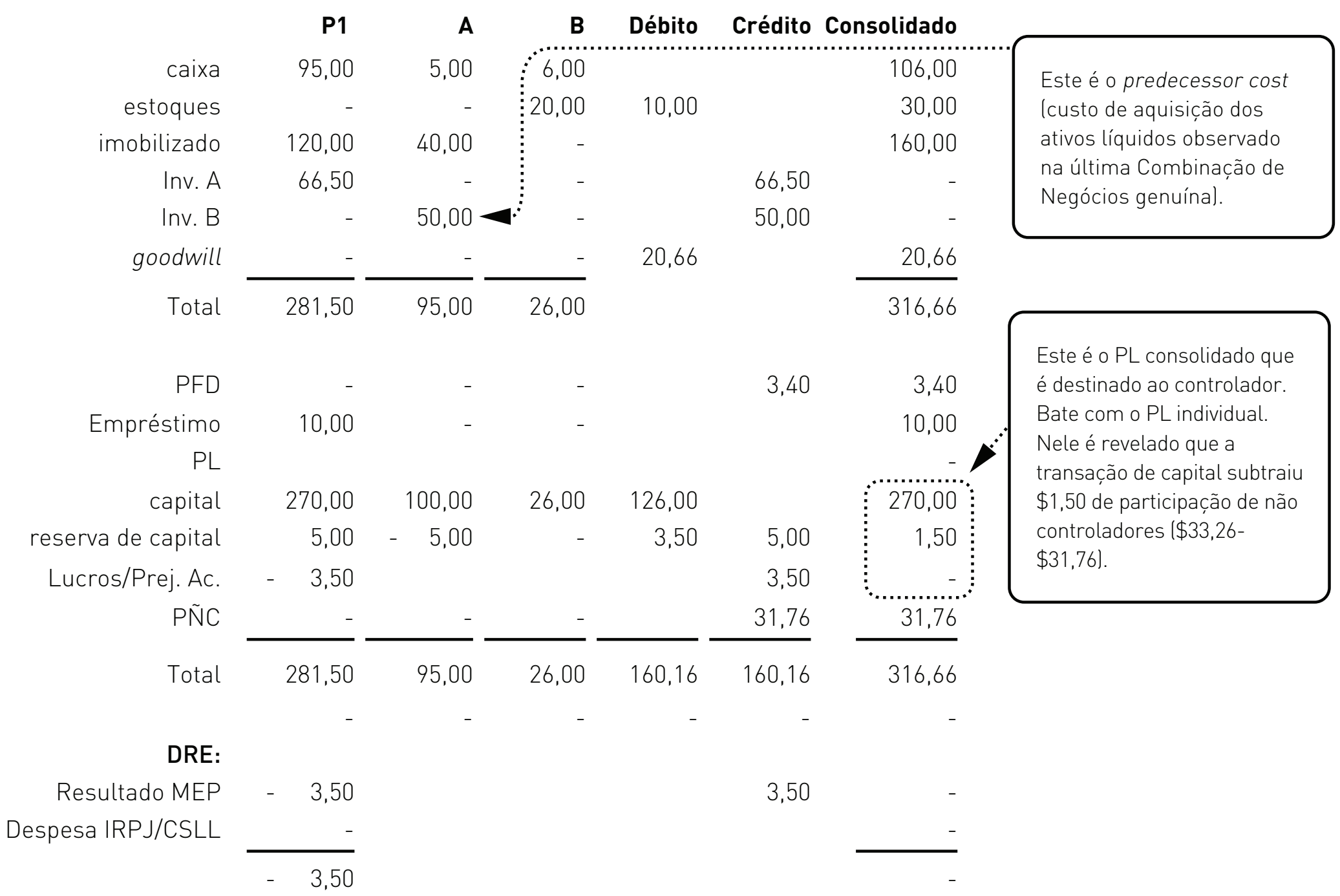

Fonte: Elaboração do autor.

reserva a parte do preço de emissão fixada para tal e nas ações preferenciais com prioridade de reembolso de capital somente a parcela que ultrapassar o valor de reembolso; no art. $182, \S 2^{\circ}$, ainda permanece a destinação da correção monetária do capital realizado para constituição da reserva. Assim, haveria um óbice legal para o reconhecimento contábil dos efeitos de uma BCUCC em rubrica de reserva de capital. Uma solução seria considerar os efeitos dentro de outros resultados abrangentes - OCI -, que abriga resultados não realizados. Importante salientar que não há previsão específica na Lei n. 6.404/1976 para OCI, mas estes são disciplinados no pronunciamento CPC 26, em seus §§90-96. 
Analisando os números, na companhia "A", a participação em "B" adquirida é reconhecida pelo seu predecessor cost de $\$ 50$ registrado em "P1" antes da sua transferência. A diferença entre a contraprestação dada em troca da participação e o predecessor cost é registrada no PL, em rubrica de reserva de capital (ou alternativamente para evitar óbices legais em rubrica de $\mathrm{OCI}$. Esses $\$ 5,00$ negativos ( $\$ 50$ - \$55) evidenciam a transferência marginal de caixa de "A" para "P1" com a operação.

Já os números da companhia "P1" evidenciam a mutação óbvia de caixa $(\$ 40+\$ 55)$, o novo valor de equivalência da participação em “A” de $\$ 66,50$ (70\% de $\$ 100$ - \$5), que gera em contrapartida um resultado com o MEP negativo de $\$ 3,50$ na DRE, e o aumento do PL com a permuta de participação em "B" ao predecessor cost de $\$ 50$ por caixa de $\$ 55$, registrado em reserva de capital de $\$ 5$. Aqui cabe um parêntese. O PL da companhia "P1" teve um aumento líquido de $\$ 1,50$ que representa justamente a parcela marginal do caixa de "A" transferida que foi suprimida dos não controladores de "A".

A análise dos números consolidados permite enxergar o que de fato ocorreu. Importante notar que, ao comparar o patrimônio consolidado antes e após a BCUCC, não houve mudança quantitativa. Permaneceu o mesmo patrimônio de $\$ 316,66$. O que ocorreu com relação à situação patrimonial anterior à BCUCC foi a mudança de participação dos sócios no patrimônio líquido. E não há qualquer resultado (desempenho de gestores) a ser reconhecido na DRE consolidada.

Dessa maneira, conforme requerem as normas contábeis norte-americanas e do Reino Unido, deve ser evidenciada a mutação qualitativa do PL. Como já salientado anteriormente, os não controladores tiveram perda de riqueza de $\$ 1,50$ e os controladores tiveram aumento de riqueza nesse mesmo montante. A Tabela 8 apresenta a demonstração da mutação do PL consolidado.

\section{TABELA 8 - DMPL CONSOLIDADA APÓS BCUCC}

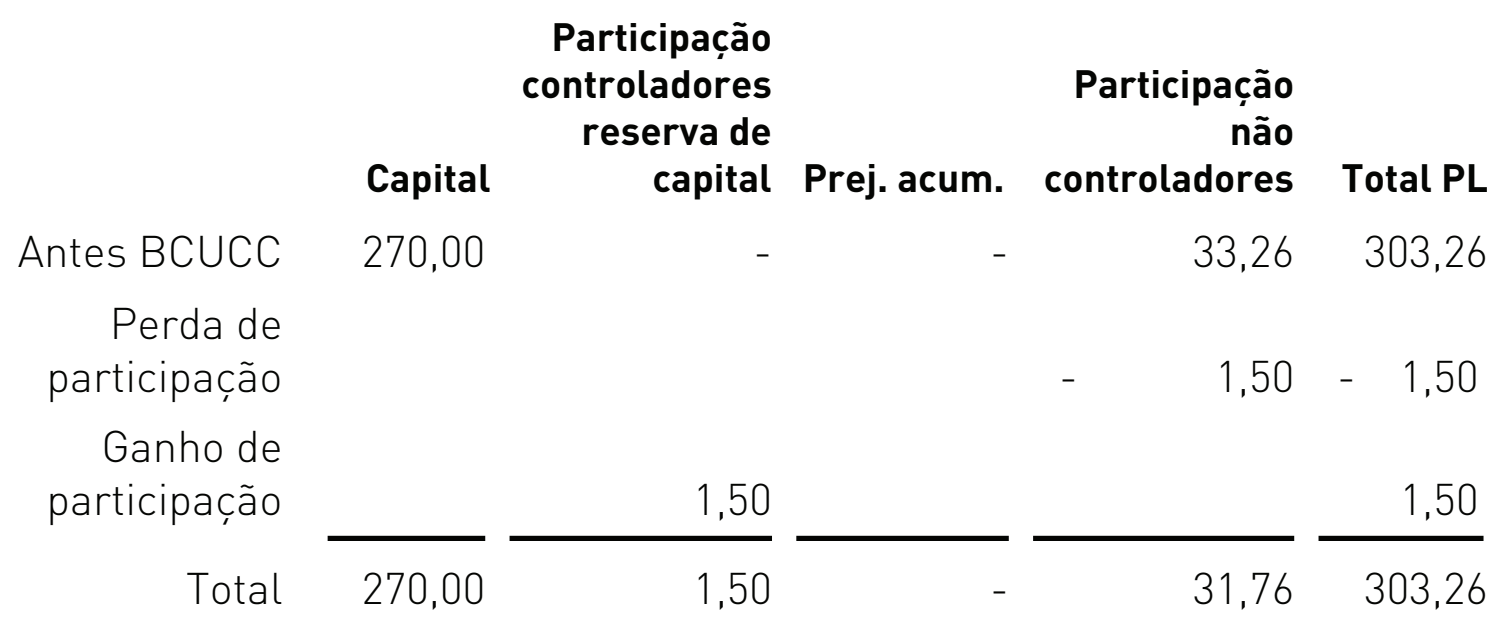

Fonte: Elaboração do autor. 
Desse modo, restou provado que a operação de BCUCC reduziu a participação de não controladores em benefício dos controladores. E isso pode configurar abuso de poder de controle, nos termos do art. 117 da Lei n. 6.404/1976, regulamentado pela Instrução CVM n. 323/2000. Como solucionar do ponto de vista societário esse problema?

Uma saída seria cancelar cinco ações de "P1" na companhia "A", com toda transparência e respeito ao devido processo, em rito a ser observado em uma assembleia geral de acionistas destinada a tratar a matéria. Afinal, na BCUCC realizada sob orientação do controlador, os controladores levaram um pedaço do PL de "A" que equivale justamente a cinco ações de emissão de "A". Com isso, não haveria perda de riqueza de não controladores. A Tabela 9 apresenta a nova distribuição de capital de "A" após ajuste.

\section{TABELA 9 - NOVA DISTRIBUiÇÃo DE CAPITAL DE “A” APÓS CANCELAMENTO DE AÇÕES}

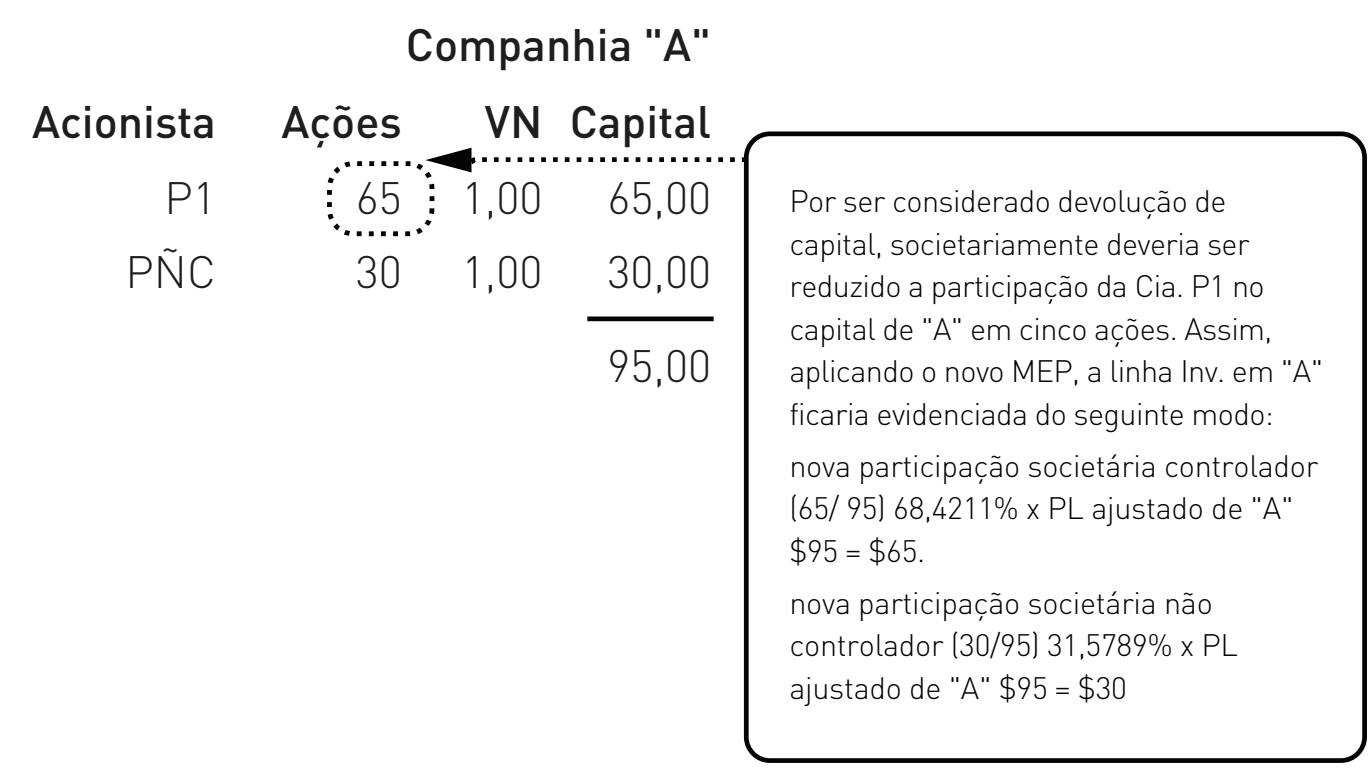

Fonte: Elaboração do autor.

E quanto ao efeito tributário? Como ficaria? Objetivamente, para a Receita Federal do Brasil (RFB), as transações são sempre tratadas com foco nas demonstrações individuais.

Assim sendo, no caso de "P1", será reconhecido um ganho de capital de $\$ 5$ com a alienação de "B”, a ser adicionado à base de cálculo do IRPJ e CSLL (a depender do período de apuração, se trimestral ou anual, e da forma de pagamento, se por estimativa ou não) e a ser escriturado no e-Lalur e no e-Lacs pela alienação da participação em "B”, ainda que se trate contabilmente de um lucro não realizado downstream. Para a RFB não existem resultados não realizados ${ }^{59} \mathrm{em}$ operações intercompanhias.

59 A título de elucidação, a ICPC n. 09, que é uma interpretação do CPC a um conjunto de normas, em seu $\S 55$ assevera que, nas operações com controladas, os lucros não realizados devem ser totalmente eliminados 
Isso está disciplinado na Lei n. 12.973/2014, art. 61, regulamentado pela Instrução Normativa (IN) n. 1.700/2017, art. 285. Reproduzem-se a seguir os incisos I e II do art. 285 da referida IN:

I - os resultados não realizados positivos a que se refere o caput que não foram registrados na escrituração comercial:

a) deverão ser integralmente adicionados na determinação do lucro real e do resultado ajustado do período de apuração da falta de registro na escrituração comercial; e

b) poderão ser excluídos na determinação do lucro real e do resultado ajustado do período de apuração em que forem registrados na escrituração comercial proporcionalmente à sua realização;

II - os resultados não realizados negativos a que se refere o caput que não foram registrados na escrituração comercial:

a) poderão ser integralmente excluídos na determinação do lucro real e do resultado ajustado do período de apuração da falta de registro na escrituração comercial; e

b) deverão ser adicionados na determinação do lucro real e do resultado ajustado do período de apuração em que forem registrados na escrituração comercial proporcionalmente à sua realização. (grifos nossos)

Já no caso de "A”, será reconhecido o custo de aquisição da participação societária em "B” por \$55. Se “A” alienar no futuro a mesma participação em “B” adquirida de "P1", poderá deduzir, nos termos da IN 1.700/2017, art. 184, os \$5 de lucros não realizados que integram o custo de aquisição da participação societária detida em "B”, evidenciados destacadamente em rubrica de ágio interno. Por outro lado, o ágio interno não será dedutível nas situações de incorporação, fusão ou cisão admitidas pela IN 1.700/2017, art. 185, por se tratar de uma BCUCC.

A Tabela 10 evidencia os cálculos de e-Lalur e e-Lacs, a ser escriturados em “P1”.

nas operações de venda da controladora para a controlada, os quais devem ser reconhecidos no resultado da controladora somente quando os ativos transacionados forem realizados (pelo uso, venda ou perda) na investida. São considerados não realizados os lucros contidos no ativo de qualquer entidade pertencente ao mesmo grupo econômico, não necessariamente na controlada para a qual a controladora tenha feito a operação original. Assim, o ganho de capital de $\$ 5$ apurado por "P1" na alienação da participação societária detida em "B" (lucro não realizado) integra o custo de aquisição da participação societária em "B" (ágio interno de \$5) registrada agora em “A". Contabilmente esse lucro não deve ser reconhecido na DRE de "P1", porém deve ser tributado. 
TABELA 10 - E-LALUR E E-LACS NA COMPANHIA “P '”

\begin{tabular}{|c|c|c|c|}
\hline e-Lalur: & $\mathrm{P} 1$ & e-Lacs: & P1 \\
\hline Lucro Contábil & $-3,50$ & Lucro Contábil & $-\quad 3,50$ \\
\hline adição Res. MEP & 3,50 & adição Res. MEP & 3,50 \\
\hline ganho/perda K & 5,00 & ganho/perda K & 5,00 \\
\hline Lucro Real & 5,00 & Result. Ajustado & 5,00 \\
\hline alíquota IRPJ & $25 \%$ & alíquota CSLL & $9 \%$ \\
\hline IRPJ a recolher & 1,25 & CSLL a recolher & 0,45 \\
\hline
\end{tabular}

Fonte: Elaboração do autor.

Considerando os efeitos tributários incidentes sobre as operações, as demonstrações contábeis são a seguir ajustadas. A Tabela 11 evidencia os números.

\section{TABELA 11 - BCUCC PELO PREDECESSOR SEM PUSHDOWN, COM EFEITOS TRIBUTÁRIOS}

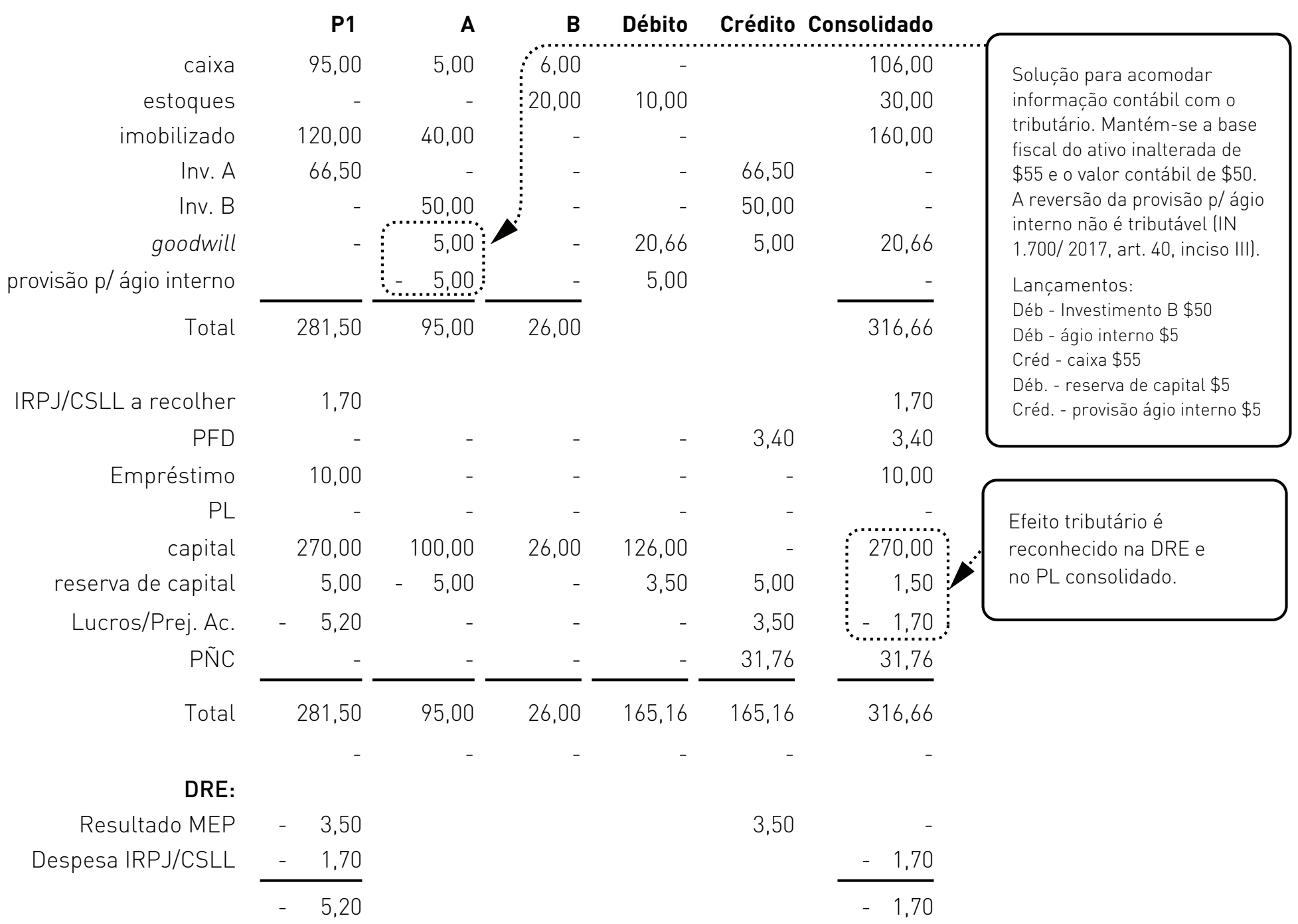

Fonte: Elaboração do autor. 
Uma saída para resguardar a qualidade da informação contábil a ser prestada pela companhia "A" e simultaneamente manter a base fiscal do ativo inalterada (participação societária em “B”) seria registrar o ágio interno de $\$ 5 \mathrm{em}$ “ $A$ ” e reconhecer uma provisão 60 para ágio interno negativa de \$5. Com isso, é apresentado o saldo contábil da participação em “B” por \$50 e, no futuro, caso a companhia “A” aliene essa mesma participação, terá como valor contábil dedutível os \$55. A reversão da provisão para ágio interno não é tributável, nos termos da IN n. 1.700/2017, art. 40, inciso III.

E a nova demonstração de mutação do patrimônio líquido, considerando os efeitos tributários, é apresentada na Tabela 12.

\section{TABELA 12 - DMPL CONSOLIDADA APÓS BCUCC, COM EFEITOS TRIBUTÁRIOS}

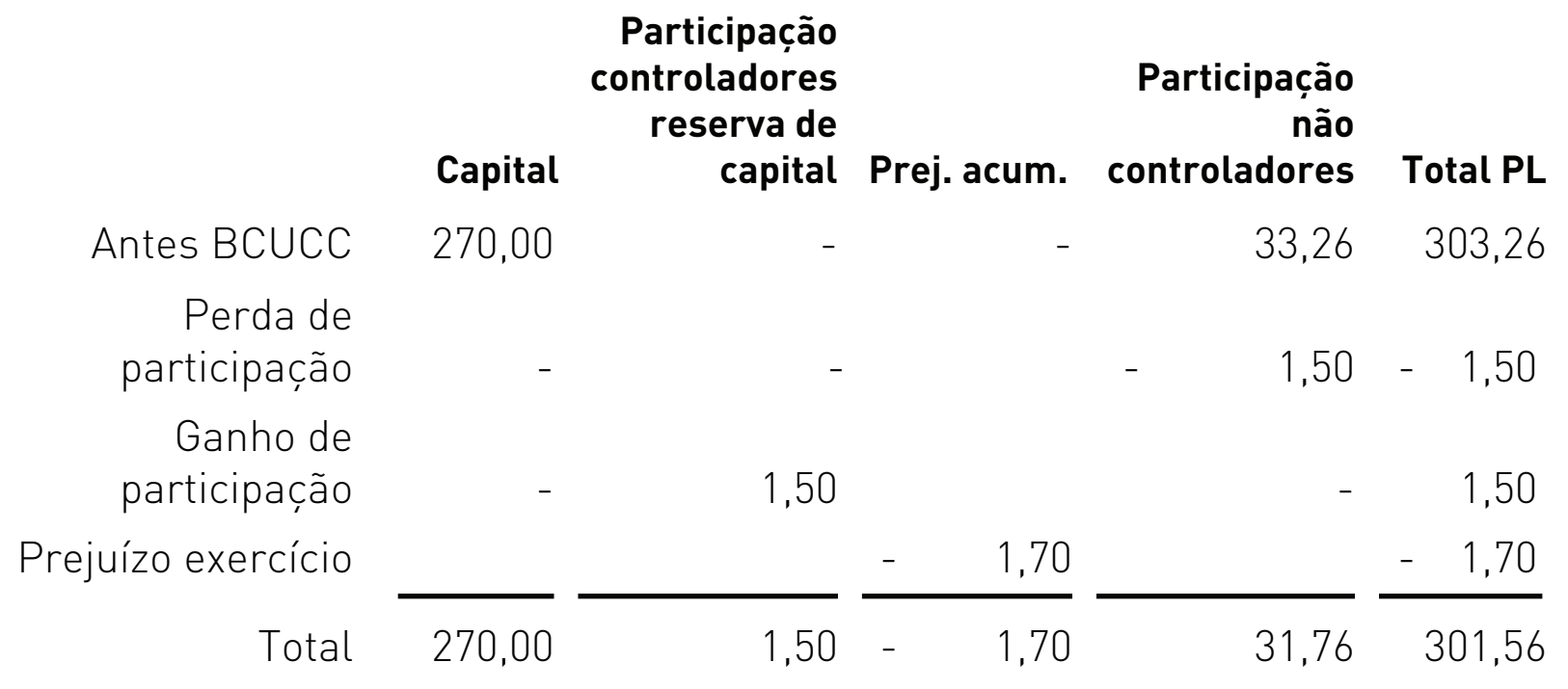

Fonte: Elaboração do autor.

\subsection{BCUCC PELO PREDECESSOR COM PUSHDOWN}

O pushdown é um método que é resultado de uma escolha contábil, conforme previsão dos USGAAP. Não há previsão nos UKGAAP, e a lei societária do Reino Unido tacitamente o

Tecnicamente, do ponto de vista das normas contábeis, não é apropriado atribuir a uma conta redutora de ativo a denominação provisão. De acordo com a IAS n. 37/CPC n. 25, provisão é um passivo de prazo ou de valor incertos. Entretanto, para acomodação com a legislação tributária, e assegurar a neutralidade do efeito fiscal, optou-se por manter a denominação "provisão para ágio interno". Ademais, essa informação só seria controlada interna e gerencialmente em razão analítico, visto que no corpo do BP a rubrica seria apresentada em termos líquidos. 
veda, mas a prática contábil entende ser o mais apropriado. Essas questões foram abordadas na seção 1.

Aplicando o pushdown ao caso de BCUCC ora estudado, "jogam-se para baixo”, no caso no balanço da adquirida "B", os valores off-balance de mais valia de estoques de $\$ 10,00$ e passivo fiscal diferido de $\$ 3,40$, reconhecidos até então somente no consolidado, e os valores de goodwill de \$20,66 e da dívida de \$10, que financiou parte da operação de aquisição de "B” por "P1", e que foram reconhecidos originalmente em "P1" quando da aquisição do controle de "B”, em uma combinação genuína (ver Tabela 4).

No patrimônio líquido de "B", como consequência do pushdown, reconhecem-se os efeitos em duas rubricas:

(i) reserva de pushdown de $\$ 20,66$ ( $\$ 10,00$ de mais-valia de estoques acrescidos de $\$ 20,66$ de goodwill e deduzidos de $\$ 10$ de dívida), que não tem previsão legal no Brasil. Alternativamente, os efeitos do pushdown poderiam ser reconhecidos em rubrica de OCI (por envolver resultados não realizados); e

(ii) IRPJ e CSLL Diferidos de $\$ 3,40$, que, nos termos do pronunciamento CPC n. 32, $\$ 61 \mathrm{~A}$, devem ser reconhecidos seguindo o reconhecimento do elemento que lhes deu origem. A mais-valia de estoques de $\$ 10$, elemento que deu origem ao IRPJ e CSLL Diferidos de \$3,40, está reconhecida dentro da reserva de pushdown.

Aqui cabe tecer algumas considerações. No Brasil, o pushdown em regra é adotado quando há uma incorporação reversa, com extinção de CNPJs. E o procedimento contábil e societário está disciplinado pela Comissão de Valores Mobiliários (CVM), na Instrução CVM n. 349/2001, que altera a Instrução CVM n. 319/1999. E assim mesmo com algumas restrições, pois a dívida que o controlador toma para financiar a aquisição da controlada não pode ser democratizada com os não controladores da controlada. Pode configurar abuso de poder de controle, nos termos do art. 117 da Lei n. 6.404/1976, regulamentado pela Instrução CVM n. 323/2000.

Outra questão diz respeito aos controles que devem ser implementados na escrituração comercial de "B" para evitar problemas com o fisco. As subcontas analíticas, para resguardar as bases fiscais e assegurar a perfeita "trilhagem" por parte dos agentes do fisco. A Tabela 13 apresenta os números. 
TABELA 13 - BCUCC PELO PREDECESSOR COM PUSHDOWN, COM EFEITOS TRIBUTÁRIOS

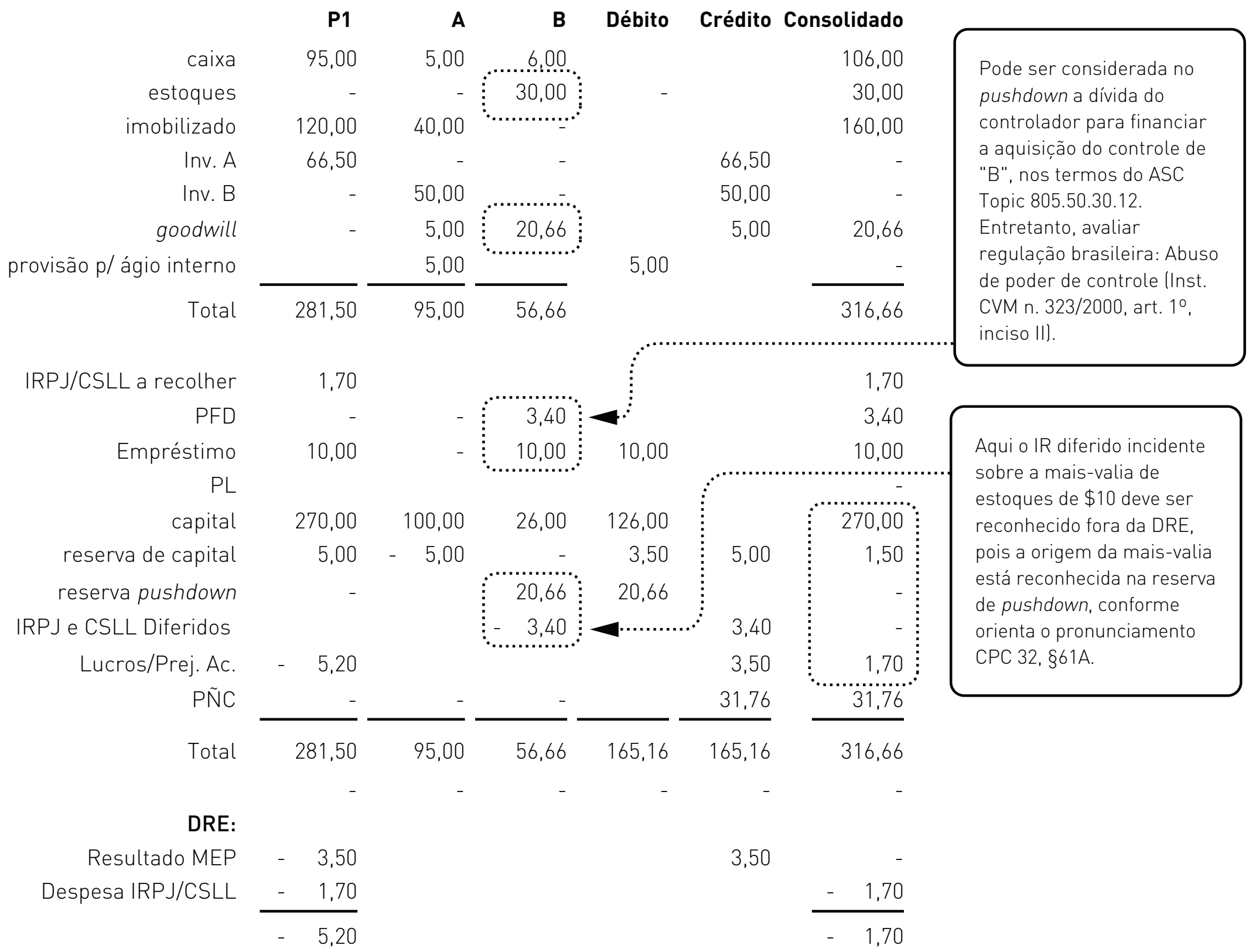

Fonte: Elaboração do autor.

Em termos informacionais, muito embora seja uma escolha contábil conferida pelos USGAAP, o pushdown a rigor só seria apropriado em aquisições de controle alavancadas, seja por empresas menores financiadas de modo alavancado por bancos de investimento (leveraged buy-outs), seja por executivos financiados de modo alavancado por bancos de investimento (management buy-outs).

\subsection{BCUCC A FAIR VALUE SEM PUSHDOWN}

A adoção do método do fair value em uma BCUCC é procedimento vedado nos USGAAP. Por outro lado, é admitido nos UKGAAP, muito embora a prática profissional entenda sê-lo inapropriado em muitos casos. A lei societária do Reino Unido ainda impõe o seu uso 
em determinadas circunstâncias. Essas questões foram abordadas na seção 1. A Tabela 14 apresenta os números para BCUCC a fair value sem pushdown, com efeitos tributários.

TABELA 14 - BCUCC A FAIR VALUE SEM PUSHDOWN, COM EFEITOS TRIBUTÁRIOS

\begin{tabular}{|c|c|c|c|c|c|c|}
\hline & P1 & A & B & Débito & Crédito & Consolidado \\
\hline caixa & 95,00 & 5,00 & 6,00 & & & 106,00 \\
\hline estoques & - & - & 20,00 & 10,00 & & 30,00 \\
\hline imobilizado & 120,00 & 40,00 & - & & & 160,00 \\
\hline Inv. A & 66,50 & - & - & & 66,50 & - \\
\hline Inv. B & - & 55,00 & - & & 55,00 & - \\
\hline goodwill & - & - & - & 25,66 & 5,00 & 20,66 \\
\hline Total & 281,50 & 100,00 & 26,00 & & & 316,66 \\
\hline RPJ/CSLL a recolher & 1,70 & & & & & 1,70 \\
\hline PFD & - & - & - & & 3,40 & 3,40 \\
\hline \multicolumn{6}{|l|}{$\mathrm{PL}$} & 10,00 \\
\hline capital & 270,00 & 100,00 & 26,00 & 126,00 & & 270,00 \\
\hline reserva de capital & 5,00 & & & 3,50 & & 1,50 \\
\hline Lucros/Prej. Ac. & - $\quad 5,20$ & & & & 3,50 & $-1,70$ \\
\hline PÑC & - & - & - & & 31,76 & 31,76 \\
\hline \multirow[t]{2}{*}{ Total } & 281,50 & 100,00 & 26,00 & 165,16 & 165,16 & 316,66 \\
\hline & - & - & - & - & - & - \\
\hline \multicolumn{7}{|l|}{ DRE: } \\
\hline Resultado MEP & - $\quad 3,50$ & & & & 3,50 & - \\
\hline \multirow[t]{2}{*}{ Despesa IRPJ/CSLL } & $\begin{array}{l}-\quad 1,70 \\
\end{array}$ & & & & & $-\quad 1,70$ \\
\hline & $-5,20$ & & & & & $-1,70$ \\
\hline
\end{tabular}

Fonte: Elaboração do autor.

A novidade nos números é o valor de custo de aquisição da participação societária detida em "B” por “A”, reconhecida ao fair value de \$55 da contraprestação dada em troca da participação. E com isso se chega à situação inusitada de serem reconhecidos dois valores para o goodwill: um no individual de $\$ 25,66$ (embutido no saldo do investimento "B”) e outro no consolidado de \$20,66. É uma configuração que pode caracterizar misleading informacional. 


\subsection{BCUCC A FAIR VALUE COM PUSHDOWN}

Por último, apresenta-se a adoção do método do fair value com o pushdown dos valores em “B”, conforme evidenciado na Tabela 15.

\section{TABELA 15 - BCUCC A FAIR VALUE COM PUSHDOWN, COM EFEITOS TRIBUTÁRIOS}

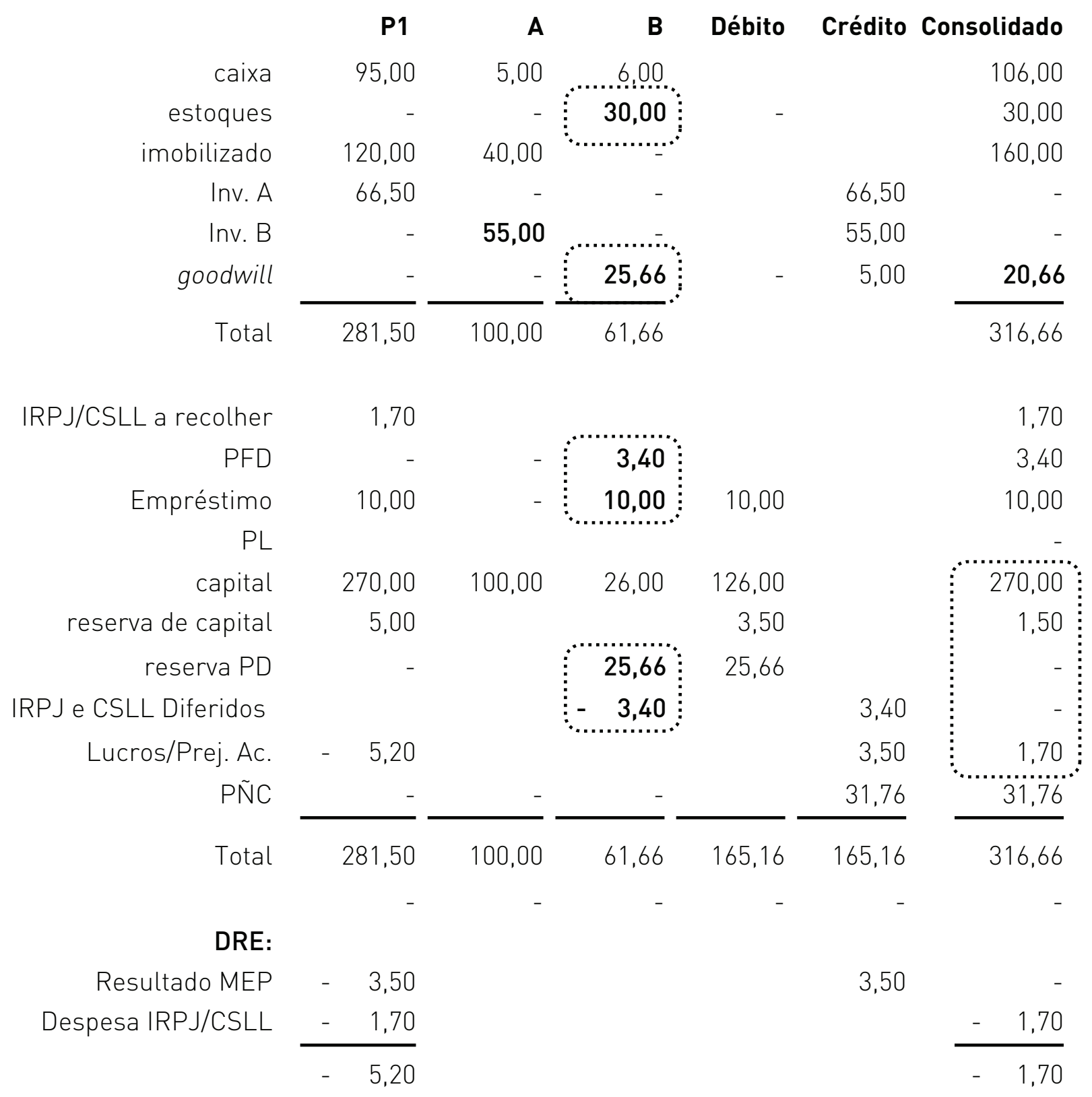

Fonte: Elaboração do autor.

Aqui cabem os mesmos comentários feitos na análise da BCUCC com predecessor e pushdown. Há a necessidade imperativa de observância de obrigações acessórias impostas pelo fisco: subcontas analíticas. E há restrições societárias com relação a determinados procedimentos que podem caracterizar abuso de poder de controle.

Importante notar que fica mais evidente com o pushdown a existência de dois valores de goodwill: de \$25,66 em “B” e de \$20,66 no consolidado. 
Ademais, conforme já asseverado, em termos informacionais, muito embora seja objeto de uma escolha contábil pelos USGAAP, o pushdown a rigor só seria apropriado em leveraged buy-outs ou em management buy-outs.

\section{CONCLUSÕES}

As combinações de negócios entre entidades sob controle comum, ou simplesmente BCUCCs, são hoje um tema de grande apelo na pauta da regulação das IFRSs, e por consequência na regulação brasileira. A lacuna observada permite que sejam desenvolvidas políticas contábeis variadas por parte da administração das companhias, promovendo com isso perda de comparabilidade e uniformidade.

Ademais, a depender das motivações econômicas subjacentes, ditas políticas podem colocar em dúvida a qualidade da informação a ser disseminada aos usuários das demonstrações contábeis. Infelizmente, a Estrutura Conceitual de Reporte Financeiro, que deveria servir como um norte para o desenvolvimento de uma política contábil, é "pedra de toque" sem função.

Pensando em BCUCCs, a Estrutura Conceitual de Reporte Financeiro, em seção dedicada à entidade que reporta, assevera no $\$ 3.14$ que os limites da entidade que reporta são direcionados pelas necessidades informacionais dos usuários primários do relatório financeiro, sendo estes definidos como investidores existentes ou potenciais, credores existentes ou potenciais e demais credores existentes ou potenciais (EC, §1.5). Esse é um assunto para os profissionais de contabilidade.

Nesse sentido, a experiência da regulação de jurisdições mais desenvolvidas, com mercados de capitais pujantes, como é o caso dos EUA e do Reino Unido, pode servir como um benchmark. Compreender os porquês para determinadas decisões tomadas em matéria de regulação contábil das BCUCCs nessas jurisdições é algo que não deve ser desprezado.

A esse respeito, restou provado, nas simulações levadas a efeito, que, para o ambiente brasileiro, a adoção de alguns procedimentos previstos nas normas estudadas dos EUA e do Reino Unido pode requerer algumas mudanças legais, sobretudo na lei societária. Por exemplo, seria imperativa uma nova disciplina legal para reserva de capital, para aplicação do método do "predecessor" (figura da paid-in reserve)? Ou ainda, uma nova disciplina legal para o ajuste da distribuição de capital da companhia transferida em uma BCUCC (cancelamento de ações de propriedade do controlador), de modo a evitar prejuízos a não controladores em termos de perda de riqueza? Isso, porém, é um assunto para os juristas que militam na área societária.

Verdade é que o tema BCUCC no Brasil estimula muitos debates e provoca algumas controvérsias. Afinal, ditas operações são motivadoras de planejamentos tributários, por vezes deveras sofisticados. Com o advento da convergência tributária às IFRSs, a Lei n. 12.973/2014 e a regulação da RFB restringiram muito o planejamento via BCUCC, mas parece que há ainda portas entreabertas (JSCP e efeitos fiscais sobre o PL). Contudo, isso é um assunto para os juristas que militam na área tributária. 
Espera-se que este artigo promova o aprofundamento do debate no Brasil, no meio acadêmico e profissional, com o envolvimento de juristas do meio societário e tributário e de profissionais de contabilidade. Afinal, para o mês de novembro de 2020, o IASB irá emitir um primeiro "discussion paper" direcionado à matéria.

\section{REFERÊNCIAS}

COMITÊ DE PRONUNCIAMENTOS CONTÁBEIS. Pronunciamento Técnico CPC 00 (R2). Estrutura conceitual para relatório financeiro. Disponível em: http: / / static.cpc.aatb.com.br/Documentos/573_ CPC00(R2).pdf. Acesso em: 5 nov. 2020.

COSTA JUNIOR, Jorge Vieira da. Planejamento tributário via BCUCC: outros resultados abrangentes como via indireta do goodwill interno. Revista de Contabilidade e Organizações, v. 13:e.164429, 2019.

COSTA JUNIOR, Jorge Vieira da; MARTINS, E. Consolidação de demonstrações contábeis: alternativas para tratamento da informação. Boletim IOB Temática Contábil e Balanços. Fascículo n. 25, jun. 2006.

DELOITTE. A roadmap to common-control transactions. New York: Deloitte, 2016.

PWC. Business combinations and non-controlling interests - application of the U.S. GAAP and IFRS Standards. EUA: PWC, 2014.

SHALEV, Ron; BONACCHI, Massimiliano; MARRA, Antonio. The effect of fair value accounting choice on the ability to raise debt. Working paper, 2014.

THE FINANCIAL REPORTING GROUP OF EY. Manual UK GAAP 2017 - Application of FRS 100-104 in the UK. UK:Wiley, 2017.

UK ACCOUNTING CONSULTING SERVICES OF PWC. Manual of accounting - New UK GAAP. London: Bloomsbury, 2013. 
ANEXO 1 - FONTE DAS TEORIAS EM CONTABILIDADE

As pesquisas/estudos em Contabilidade, em síntese, são conduzidas sob duas abordagens, a saber: abordagem normativa, que procura avaliar a repercussão da aplicação de um ou mais benchmark normativos indicados pelo autor ou de uma proposta normativa desenhada pelo autor, nos números das simulações trabalhadas (e já trazem intrinsecamente o "ideal econômico" do lucro a ser medido), e abordagem positiva, que procura investigar determinados fenômenos contábeis (escolhas contábeis, por exemplo, ou o conteúdo informacional de um tratamento contábil específico), a fim de tentar explicá-los e predizê-los (tendo como plataforma teorias econômicas).

Em trabalho seminal, que rompeu a fronteira da pesquisa e do conhecimento em Contabilidade, intitulado “An Empirical Evaluation of Accounting Income Numbers”, os professores Ray Ball e Philip Brown comprovaram empiricamente a relevância dos números contábeis e colocaram por terra algumas crenças advogadas por normativistas, dentre as quais a de que o lucro, por decorrer de um mix de critérios de mensuração, não teria sentido econômico. Uma falácia normativista.

Interessante observar que o paper de Ball e Brown foi rejeitado pelo The Accounting Review, o periódico mais tradicional e um dos top five, muito bem-conceituado até os dias de hoje pela academia norte-americana, pelo fato de ter muito pouco a ver com Contabilidade, segundo a visão dos então editor e revisores da revista. A revista era dominada pelo pensamento de normativistas. Inauguraram a pesquisa positivista em Contabilidade sob enfoque do conteúdo informacional.

Outro avanço na pesquisa positivista foi promovido pelos ilustres professores Ross L. Watts e Jerold L. Zimmerman, que, no final da década de 1970, em artigo seminal, intitulado "Towards a Positive Theory of the Determination of Accounting Standards" (The Accounting Review, 1978), procuraram desenvolver um modelo para explicar e predizer escolhas contábeis que gestores têm ao seu dispor sob uma abordagem contratual. As escolhas contábeis seriam resultantes de conflitos de agência observados entre agente e principal, cujas motivações encontram explicação nas hipóteses do nível de endividamento, do custo político e do plano de remuneração de executivos (bonus plan).

Enfim, pesquisadores positivistas encaram cientificamente a Contabilidade de um modo indutivo, pois olham para a realidade antes de formularem suas hipóteses / teorias (são "empiristas"). Investigam, por exemplo, o que motiva os gestores a fazerem determinadas escolhas contábeis (com variantes na literatura para modelos de gerenciamento de resultados e para modelos de medição da qualidade da informação contábil). Ou, à luz da hipótese de mercado eficiente, e considerando modelos consagrados e documentados na literatura de finanças (CAPM, por exemplo), investigam qual seria a relevância de determinada informação contábil (impacto nos preços da ação da companhia).

Já os pesquisadores normativistas encaram cientificamente a Contabilidade de um modo dedutivo, pois recorrem a argumentos lógicos, a partir de um modelo prévio definido, para 
desenvolverem "teorias". Buscam o "ideal econômico" do lucro a ser medido. As teorias por assim dizer "normativas", subjacentes aos elementos contábeis (ativo, passivo, PL, receita e despesa, ganhos e perdas, $\mathrm{OCI}$ ), a rigor, não explicam e predizem fenômenos observados (não derivam de observações empíricas). São argumentos esposados, a partir de arcabouços conceituais previamente definidos para um "ideal econômico" de lucro, que resultam na definição de capital e de manutenção de capital, que se aproximam também de conceitos econômicos (lucro em termos físicos, lucro em termos nominais, lucro em termos de moeda de capacidade aquisitiva constante, lucro em termos físicos considerando simultaneamente a moeda de capacidade aquisitiva constante).

Em um clássico normativo da área, os autores Eldon S. Hendricksen e Michael F. Van Breda (Accounting theory, $5^{\text {th }}$ ed., 1992), em capítulo intitulado "Introduction and Methodology of Accounting", apresentam bases mais amplas para o desenvolvimento de teorias normativas, a saber: motivação tributária, motivação legal, motivação ética, motivação econômica, motivação comportamental e motivação estrutural (arcabouço conceitual). O quadro a seguir, a título de contribuição para o debate, sintetiza os enfoques teóricos normativos, segundo Hendricksen e Van Breda (1992):

\begin{tabular}{ll}
\hline EXHIBIT 1-1 & Questions to Ask \\
\hline Tax & What is the tax situation? \\
Legal & What is required by law? Are there any specific regulations \\
covering this industry? \\
Ethical & What is the right thing to do? Is this fair presentation? \\
Economic & What effect will this accounting procedure have on the econ- \\
& omy? What effect will this choice of accounting procedure \\
have on shareholders? Is there full disclosure of the facts \\
behind the procedure? What effect will this have on other \\
stakeholders? \\
Why does management want to make this choice? \\
Behavioral & $\begin{array}{l}\text { Is there a specific rule covering this situation? What is the defi- } \\
\text { nition of revenue? What is GAAP? What are others doing in } \\
\text { the industry? }\end{array}$
\end{tabular}




\section{ANEXO 2 - EVIdÊNCIA EMPÍRICA PARA EXPLICAR AS BCUCCS A FAIR VALUE - HiPÓTESE}

\section{DO WINDOW DRESS}

Em trabalho sob uma abordagem positivista de pesquisa, Shalev, Bonacchi e Marra (2014) apresentaram como uma possível hipótese/teoria para o fenômeno das BCUCCs a fair value o efeito window dress.

Segundo os autores, as BCUCCs decorrem de uma escolha contábil oportunística (opportunistic accounting choice), por meio da qual as companhias remensuram seus ativos ao fair value (inflam-nos), reduzindo com isso a alavancagem. Subsequentemente ao evento, promovem a colocação pública de títulos de dívida em vez da colocação privada, que é destinada majoritariamente aos bancos, que são imunes aos efeitos do window dress (os autores advogam que há maior assimetria informacional em colocações públicas e menor monitoramento do que o realizado por bancos nas colocações privadas).

O estudo foi feito com 147 companhias europeias. A tabela a seguir reproduzida indica as evidências empíricas coligidas pelos autores. O modelo de regressão OLS dos autores evidencia que a mudança na alavancagem das companhias está negativamente correlacionada com o fair value dos ativos líquidos (efeito window dress). E significância estatística é bem conservadora para o estimador da variável fair value: 1\%. A alavancagem é metrificada pelo total de Passivo/PL e total de Passivo/total de ativos (colunas 1 e 2 do painel). 


\begin{tabular}{|c|c|c|c|}
\hline \multicolumn{4}{|c|}{$\begin{aligned} \text { LEVERAGE_CH } & =\beta_{0}+\beta_{1} \text { FV_BCUCC }_{i}+\beta_{2} \text { SIZE }_{i} \\
& +\beta_{3} \text { MT B }_{i}+\beta_{4} \text { CASH }_{i}+\beta_{5} \text { CAPEX }_{-} \text {CH }_{i}+\beta_{6} \text { ROA }_{i}+\beta_{7} \text { MINORITY }_{i}+\varepsilon_{i}\end{aligned}$} \\
\hline Variables & Prediction & \multirow{2}{*}{$\begin{array}{c}\text { Column } 1 \\
\qquad / \boldsymbol{E} \\
-0.065 \\
(-0.48)\end{array}$} & \multirow{2}{*}{$\begin{array}{c}\text { Column } 2 \\
D / T A \\
0.022 \\
(0.50)\end{array}$} \\
\hline Intercept & & & \\
\hline$F V_{-} B C U C C$ & $-1+/ / 2 /+$ & $\begin{array}{c}-0.141^{* 4 k} \\
(-2.63)\end{array}$ & $\begin{array}{c}-0.068^{*+4} \\
(-2.87)\end{array}$ \\
\hline SIZE & $?$ & $\begin{array}{c}-0.004^{* * *} \\
(-2.19)\end{array}$ & $\begin{array}{c}-0.005^{* * *} \\
(-5.43)\end{array}$ \\
\hline MTB & $?$ & $\begin{array}{l}0.004 \\
(0.65)\end{array}$ & $\begin{array}{l}0.001 \\
(0.72)\end{array}$ \\
\hline $\mathrm{CASH}$ & $?$ & $\begin{array}{r}-0.000 \\
(-0.31)\end{array}$ & $\begin{array}{l}0.001^{*} \\
(1.71)\end{array}$ \\
\hline CAPEX_CH & $?$ & $\begin{array}{l}0.016 \\
(0.88)\end{array}$ & $\begin{array}{r}-0.001 \\
(0.13)\end{array}$ \\
\hline ROA & $?$ & $\begin{array}{l}0.243^{*} \\
(1.85)\end{array}$ & $\begin{array}{l}0.031^{*} \\
(1.84)\end{array}$ \\
\hline MINORITY & $?$ & $\begin{array}{l}0.027 \\
(0.60)\end{array}$ & $\begin{array}{l}0.022 \\
(0.51)\end{array}$ \\
\hline Industry, Country, and Year Fixed Effects & & Yes & Yes \\
\hline \# of Observations & & 230 & 230 \\
\hline$R$-squared & & 0.182 & 0.167 \\
\hline 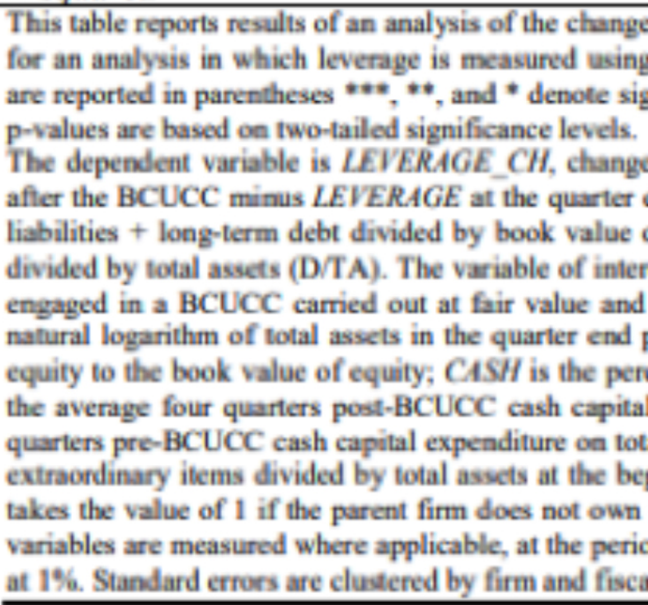 & 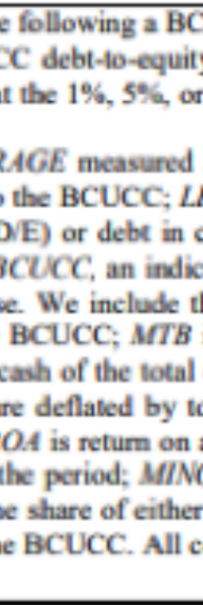 & $\begin{array}{l}\text { C. Column } 1 \text { (2 } \\
\text { lobt to assets) } \mathrm{r} \\
\text { \% level, respec } \\
\text { LEVERAGE at } \\
\text { SRAGE is either } \\
\text { ent liabilities + } \\
\text { variable equal } \\
\text { following contr } \\
\text { he ratio of the } \\
\text { sideration paid } \\
\text { assets minus } \\
\text { ts measured as } \\
\text { TY is an indica } \\
\text { target or the a } \\
\text { inuous variable: }\end{array}$ & $\begin{array}{l}\text { reports results } \\
\text { tiv. Z-statistics } \\
\text { ively. Reported } \\
\text { the quarter end } \\
\text { debt in current } \\
\text { long-term debt } \\
\text { to } 1 \text { if the firm } \\
\text { ls: SIZE is the } \\
\text { narket value of } \\
\text { CAPEX_CH is } \\
\text { e average four } \\
\text { eamings before } \\
\text { of variable that } \\
\text { quirer. Control } \\
\text { are winsorized }\end{array}$ \\
\hline
\end{tabular}




\section{ANEXO 3 - DisPosições TRIBUTÁRIAS PARA AS BCUCCS}

\section{LEI N. I 2.973, DE I 3 DE MAIO DE 2014}

Dedutibilidade da “MAis-valia”: SÓ PARA aquela originada EM CombinaÇÃo de Negócios entre Partes NÃo DePendentes:

Art. 20. Nos casos de incorporação, fusão ou cisão, o saldo existente na contabilidade, na data da aquisição da participação societária, referente à mais-valia de que trata o inciso II do caput do art. 20 do Decreto-Lei n ${ }^{0}$ 1.598, de 26 de dezembro de 1977, decorrente da aquisição de participação societária entre partes não dependentes, poderá ser considerado como integrante do custo do bem ou direito que lhe deu causa, para efeito de determinação de ganho ou perda de capital e do cômputo da depreciação, amortização ou exaustão. (grifos nossos)

\section{Dedutibilidade do GOODWILl: Só PARA AQUele originado EM CombinaÇão de Negócios ENTRE PARTES NÃO DEPENDENTES:}

Art. 22. A pessoa jurídica que absorver patrimônio de outra, em virtude de incorporação, fusão ou cisão, na qual detinha participação societária adquirida com ágio por rentabilidade futura (goodwill) decorrente da aquisição de participação societária entre partes não dependentes, apurado segundo o disposto no inciso III do caput do art. 20 do Decreto-Lei n ${ }^{\circ} 1.598$, de 26 de dezembro de 1977, poderá excluir para fins de apuração do lucro real dos períodos de apuração subsequentes o saldo do referido ágio existente na contabilidade na data da aquisição da participação societária, à razão de 1/60 (um sessenta avos), no máximo, para cada mês do período de apuração. (grifos nossos)

\section{Conceito legal de partes dependentes}

Art. 25. Para fins do disposto nos arts. 20 e 22, consideram-se partes dependentes quando:

I - o adquirente e o alienante são controlados, direta ou indiretamente, pela mesma parte ou partes;

II - existir relação de controle entre o adquirente e o alienante;

III - o alienante for sócio, titular, conselheiro ou administrador da pessoa jurídica adquirente;

IV - o alienante for parente ou afim até o terceiro grau, cônjuge ou companheiro das pessoas relacionadas no inciso III; ou

$\mathrm{V}$ - em decorrência de outras relações não descritas nos incisos I a IV, em que fique comprovada a dependência societária.

Parágrafo único. No caso de participação societária adquirida em estágios, a relação de dependência entre o(s) alienante(s) e o(s) adquirente(s) de que trata este artigo deve ser verificada no ato da primeira aquisição, desde que as condições do negócio estejam previstas no instrumento negocial. (grifos nossos) 


\section{INSTRUÇÃO NORMATIVA RFB N. I.700, DE I 4 DE MARÇO DE 2017}

Regulamentação dos arts. 20 e 22 da Lei n. 12.973/2014 pelos arts. 185 e 186 da IN RFB n. $1.700 / 2017$.

Regulamentação do art. 25 da Lei n. 12.973/2014 pelo art. 189 da IN RFB n. 1.700/2017. 


\section{ANEXO 4 - "Merger RelieF" vs. "ReCONSTRUCtion RelieF"}

\section{“Merger Relief”:}

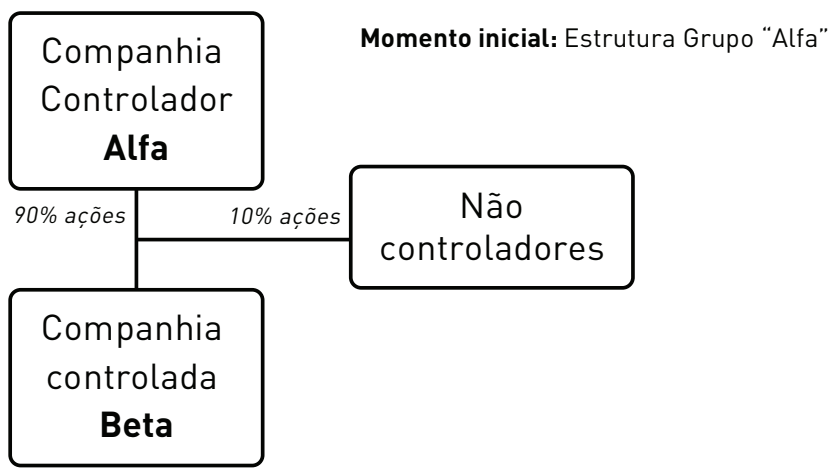

“Reconstruction Relief":
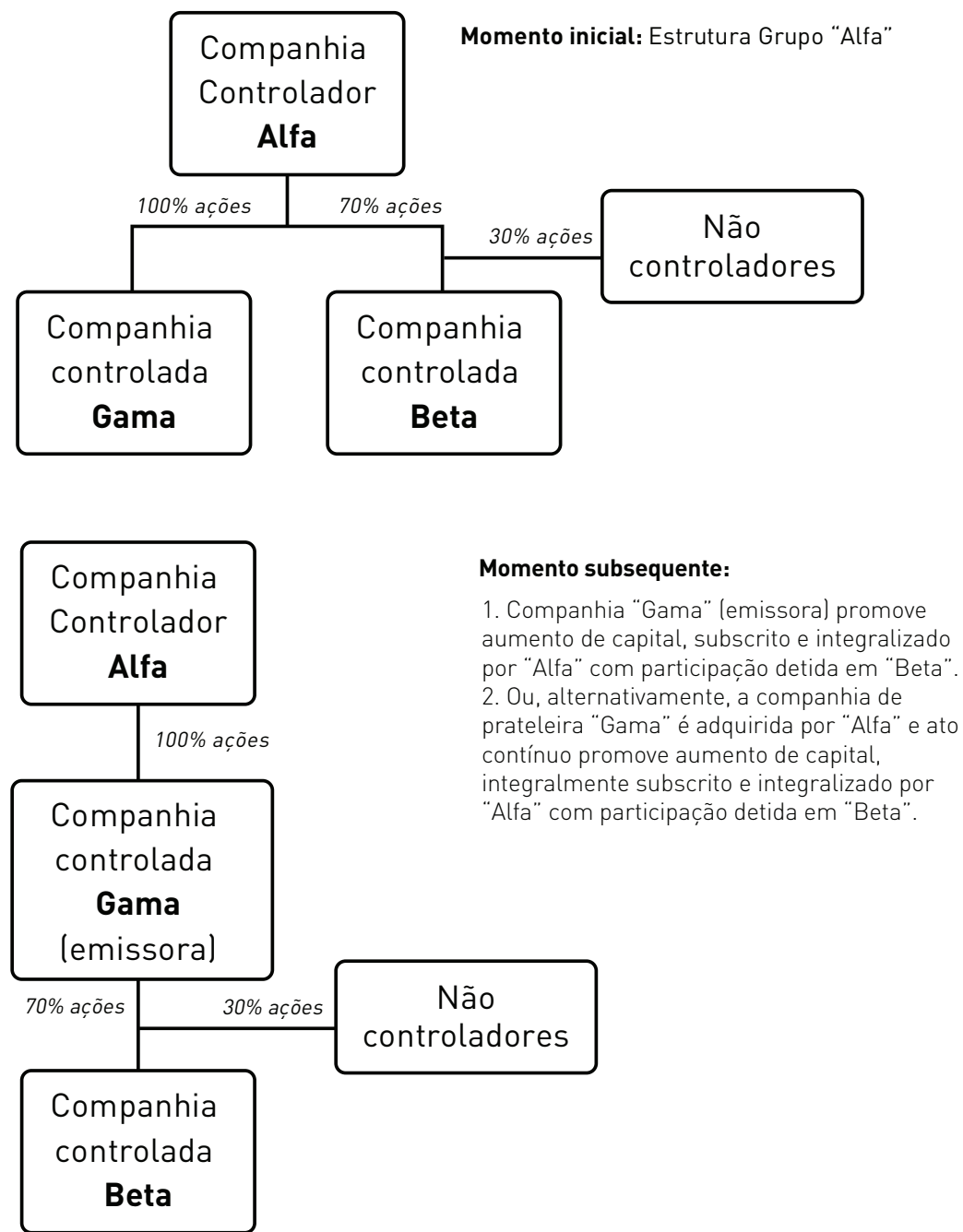

Obs.: Uma companhia de prateleira (off-the-shelf company) é uma companhia limitada pré-registrada na junta comercial do Reino Unido ("Companies House"), que jamais teve qualquer operação, e pronta para ser adquirida.

\section{COMO CITAR ESTE ARTIGO:}

COSTA JUNIOR, Jorge Vieira da.

Combinação de negócios entre entidades sob controle comum: um estudo dos USGAAP e dos UKGAAP e seus efeitos no ambiente societário e tributário brasileiro. Revista Direito GV, v. 16, n. 3, set./dez. 2020, e1973. doi: http://dx.doi.org/10.1590/23176172201973.

\section{Jorge Vieira da Costa Junior}

Doutor em Controladoria e Contabilidade PELA Universidade de São Paulo (USP). Professor do departamento de Contabilidade da Universidade Federal Fluminense (UFF). Líder de Grupos de Pesquisa cadastrados no CNPQ: GRUPO DE

Pesquisa EM Contabilidade, FInANÇAS E TRIBUtAÇÃO - GPCFT (HTTP://DGP.CNPQ.BR/DGP/ESPELHOGRUPO/338590) E OBSERVATÓRIO UFF dA REGULAÇÃO CONTÁBIL INTERNACIONAL (HTTP:// DGP.CNPQ.BR/DGP/ESPELHOGRUPO/485978).

jorgevieiralaid.uff.br 